\title{
WEALTH EFFECTS OF SEASONED EQUITY OFFERINGS: A META
}

\author{
ANALYSIS \\ Chris Veld*, \\ Monash University \\ E-mail: chris.veld@monash.edu \\ Patrick Verwijmeren, \\ Erasmus University Rotterdam, University of Melbourne, and University of Glasgow \\ E-mail: verwijmeren@ese.eur.nl \\ Yuriy Zabolotnyuk, \\ Carleton University \\ E-mail: yuriy.zabolotnyuk@carleton.ca
}

June 13, 2018

Keywords: seasoned equity offerings, rights issues, wealth effects, meta-analysis

JEL-codes: G14, G30, G32

\footnotetext{
* Corresponding author: Monash Business School, Department of Banking and Finance, Caulfied Campus, 990 Dandenong Road, Caulfield Vic 3145, Melbourne, Australia. E-mail: chris.veld@monash.edu. The paper has benefitted from comments and suggestions from Seth Armitage, Abe de Jong, Eric Duca, Marie Dutordoir, Giancarlo Giudici, Frank Hong Liu, Brian Lucey, Daniel Hung, Alper Kara, Igor Loncarski, Geoffrey Poitras, Jay Ritter, and of participants at the Multinational Finance Conference in Halkidiki (June 2015), the International Review of Financial Analysis Symposium on Meta-analysis in International Finance in Poznan (June 2018), and seminar participants at the University of Glasgow, University of Loughborough, and Simon Fraser University. The authors gratefully acknowledge the excellent research assistance of Tim Kooijmans, Gillian MacIver, Hang Pham, and Angel Zhong. Special thanks go to the Associate Editor and the anonymous referee for their very useful comments.
} 


\title{
WEALTH EFFECTS OF SEASONED EQUITY OFFERINGS: A META ANALYSIS
}

\begin{abstract}
:
We use meta-analysis to review studies on announcement effects associated with seasoned equity offerings. Our sample includes 199 studies from 38 leading finance journals and SSRN working papers. The studies cover different countries, but the U.S. is particularly well-represented with 131 studies. We find a statistically significant mean cumulative abnormal return of $-0.98 \%$. Abnormal returns are more negative for equity issues by U.S. companies and for non-U.S. rights issues and are less negative for private placements. In addition, wealth effects are more negative when the proceeds are used for debt reduction, when the SEO is issued shortly after IPO, and for issues by non-dividend-paying companies and industrial companies. We identify important avenues for future research.
\end{abstract}




\section{Introduction}

Companies that need capital often turn to Seasoned Equity Offerings (SEOs) to fulfil their financial needs. Over the period 2000 to 2011, U.S. companies alone raised \$1,146 billion with SEOs. ${ }^{1}$ SEOs are particularly important for firms that want to finance growth opportunities. Interestingly, a wide range of studies around the world find that announcements of SEOs are associated with negative abnormal stock returns. For example, an overview paper of Eckbo and Masulis (1995) finds average abnormal returns of $-3.1 \%$ for U.S. SEOs. These negative abnormal returns are generally explained by two theories. The theory of Myers and Majluf (1984) is based on asymmetric information between managers and shareholders. In their model, a SEO is perceived as bad news because the market will assume that managers, who have better information than shareholders, try to sell overpriced equity. The market timing theory of Baker and Wurgler (2002) argues that managers try to time the market and issue equity when valuations are highest. This theory is also consistent with negative abnormal returns around the announcement of an SEO.

Many empirical studies outside the U.S. also find negative abnormal returns, but the results in several countries paint a different picture. A potential explanation for differences across countries relates to the characteristics of the offerings. For example, the popularity of rights offerings varies across countries. However, to confuse matters, attributes have been linked to more positive announcement effects in some studies, while they are linked to more negative announcement effects in other studies.

In this paper we aim to systematically analyze the many papers on SEOs that present different findings for different countries and for different attributes of SEOs. For this purpose, we use metaanalysis. Until now, this technique has not been used very often in finance research, but it is more widely applied in other disciplines, such as epidemiology, education, and management. ${ }^{2}$ The specific type of meta-analysis that we use is generally referred to as replication analysis. In this replication analysis we conduct regression analyses that summarize a wide range of existing studies. The abnormal returns that are reported in previous empirical studies are the dependent variable in these regression analyses. This type of meta-analysis combines insights from a wide range of studies and allows us to draw statistically strong conclusions on systematic country differences and/or differences associated with other characteristics of SEOs. A related advantage is that this type of analysis is more objective than a traditional literature review and allows for a test of a potential publication bias.

\footnotetext{
${ }^{1}$ Over the same period, they raised $\$ 510$ billion with convertible debt issues and $\$ 6,635$ billion with straight debt issues (Dutordoir, Lewis, Seward, and Veld, 2014).

${ }^{2}$ One recent exception in finance is the meta-analysis of relationship lending by Kysucky and Norden (2016).
} 
We look for papers that present event period abnormal returns associated with SEO announcements. The first source is a list of 38 leading academic finance journals. The second source consists of unpublished working papers (per December 31, 2017) that are available on the Social Sciences Research Network (SSRN). We find 199 studies that present abnormal returns associated with SEOs of which 161 papers are published in our list of journals and 37 studies are found on SSRN. These studies include a total of 861 sub-sample results. The mean abnormal return for seasoned equity offerings is $-0.98 \%$ and the median is $-1.39 \%$.

Several findings emerge from our regression analysis. We find that rights issues are associated with more negative abnormal returns. Private placements, on the other hand, are associated with less negative announcement returns. When we study the interaction between rights issues and U.S. studies, we find that this interaction term is positive, but we also establish that U.S. issues in general are associated with more negative abnormal returns.

Interestingly, we do not find that information asymmetry has a significant effect on announcement returns. We do find evidence that SEOs that are done for paying back debt are associated with more negative abnormal returns. This result is in line with firms not fully exploiting the corporate tax shield associated with debt financing (Graham, 2000). Dividend-paying companies that issue equity generally see less negative abnormal returns than non-dividend-paying companies that issue equity.

Another interesting aspect of our study is that it allows for a comparison between the announcements returns in different types of publications. All else equal, we find that the announcement returns in Top-4 journals are higher than those published in other journals and in SSRN working papers.

Our paper provides avenues for future research. The fact that a disproportional number of studies are on U.S. data, combined with the differential wealth effects around the world, suggests that there is still ample room to study wealth effects in other countries, especially when institutional features differ. For example, we document that the effects of rights issues differ between U.S. and non-U.S. issuers. This finding calls for a worldwide study on rights issue, especially as countries differ in the extent to which existing shareholders in a rights issue are entitled to sell their rights if they do not wish to obtain more shares. Future research opportunities are also provided by factors that show up as significant in our meta-analysis but that have not been researched extensively. An example is the relevance of the stated use of proceeds. A further examination of these factors could lead to an even better understanding of the cost of issuing equity.

The remainder of this study is organized as follows: Section 2 briefly reviews the studies on the wealth effects that are associated with announcements of seasoned equity issues. Section 3 includes a discussion of the factors that have the potential to explain these wealth effects. The model for the meta- 
analysis is included in Section 4. Section 5 describes the results, and the paper is concluded in Section 6 with a discussion of the implications of the results.

\section{Wealth effects of seasoned equity offerings}

An extensive set of event studies on announcements of seasoned equity offerings have been undertaken. All these studies document results for abnormal returns associated with the announcement. Some of these results are positive and significant, some are negative and significant, and others are not significant. We review these studies by using a meta-analysis technique. We follow the approach of Datta, Pinches, and Narayanan (1992), Veld and Veld-Merkoulova (2009), and Abdul Rahim, Goodacre, and Veld (2014), who use meta-analysis to study the wealth effects associated with the announcement of mergers and acquisitions, spin-offs, and convertible bonds and warrant-bond offerings, respectively. In the meta-analysis in this paper, the estimates of the abnormal returns associated with issuances of seasoned equity are used as observations in a multi-factor setting. The abnormal returns are the dependent variable and certain SEO characteristics are the independent variables. A multiple regression analysis is used to assess the impact of each factor on the dependent variable, with the factors corresponding to those that earlier studies hypothesized to influence the creation of wealth.

We start our search for papers that present wealth effect results for seasoned equity announcements by searching a list of 26 core finance journals identified by the study of Heck and Cooley (2009), who in turn base this set on several previous studies. This list is presented in Table 1.

[Please add Table 1 here]

The list of 26 journals of Heck and Cooley (2009) is slightly biased towards U.S. studies. For that reason, we add 12 journals to the list that mostly focus on European and generally non-U.S. studies: Accounting and Finance, Critical Finance Review, European Financial Management, International Review of Finance, International Review of Financial Analysis, Journal of International Financial Markets, Institutions and Money, Journal of International Money and Finance, European Journal of Finance, Journal of Business, Review of Asset Pricing Studies, Review of Corporate Finance Studies, and Review of Finance (formerly European Finance Review). 
We include all studies that are published in the list of journals before December $31,2017 .{ }^{3}$ To test for a publication bias, we also include working papers. Since it is impossible to capture all working papers that present results of announcements of equity issues, we restrict ourselves to working papers that are included in the library of the Social Sciences Research Network (SSRN). We include all SSRN working papers that are dated December 31, 2017 or earlier. We only include papers in English.

Table 1 presents the source of the papers in our study. In total we have 198 papers of which 161 are journal publications and 37 are SSRN working papers. ${ }^{4}$ According to Table 1, the journals that published the most event studies on seasoned equity issues are Journal of Financial Economics (22), Journal of Corporate Finance (21), and Journal of Banking and Finance (12). A total of 11 journals did not publish any event study on seasoned equity issues. The latter result is not surprising, because some of the journals are clearly outside corporate finance, such as Journal of Derivatives and Journal of Money, Credit, and Banking.

Table 2 presents a review of the most important results from the 199 studies.

[Please insert Table 2 here]

This table presents the source of the study, the country of the study, the research period analyzed, the main event window, the number of observations, and the average cumulative abnormal return (CAR). The table is split up in market-oriented economies and network-oriented economies, using the definition of Moerland (1995). The first papers are on U.S. data and are published in 1985. The most recent papers were forthcoming at the beginning of 2018. As is the case with most topics in finance, most of the papers are about the United States (131 papers). However, there are also many studies on countries outside the U.S. In total, 60 papers cover individual other countries such as the United Kingdom (9), China (7), Japan (6), Taiwan (6), France (5), Hong Kong (5), and Canada (3). Other countries are covered by one or two studies. Finally, eight studies have an international sample.

Most of the papers find significant negative abnormal returns. This result especially holds for the U.S. However, some U.S. studies find significant positive abnormal returns. For example, Hertzel and Smith (1993) find a significant cumulative abnormal return of 1.72\% over the 4-day event window (3,0). Outside the U.S., while most of the studies find negative abnormal returns, it is even more common that studies for the same country report contradictory results. For example, Tsangarakis (1996) finds a positive and significant abnormal return for Greece (3.97\%), while Espenlaub, Siougle, and Strong

\footnotetext{
${ }^{3}$ We also include the papers that are published on-line on the websites of the journals per December 31, 2017. In some of these cases, the paper publication occurred in 2018.

${ }^{4}$ The 199 studies that we have stem from 198 papers. The reason is that the paper by Holderness (2018) contains two separate studies: one for the U.S. and one for Australia.
} 
(2008) find a negative and significant abnormal return (-1.37\%). Potential explanations for these differences include differences in sample periods, or differences in the characteristics of the offerings.

\section{Factors explaining wealth effects of seasoned equity offerings}

The empirical corporate finance literature studies many factors that are related to wealth effects associated with SEOs. To do a sensible econometric analysis, our meta-analysis only includes factors that are studied in at least three empirical studies. We briefly summarize these factors next.

\subsection{Rights offerings}

Although rights offerings are not as popular anymore in the United States as in the U.K., Australia, continental Europe, and Asia (e.g. Eckbo and Masulis, 1992; Eckbo, 2008), studies have shown that they do typically result in higher announcement effects than other SEOs, like firm commitment offerings. The wealth effects that most studies in the U.S. find for rights offering announcements are negative, but relatively these effects are less negative than for other SEOs (Smith, 1977; Eckbo and Masulis, 1992; Eckbo, 2008). One reason for the relatively good announcement effects is that rights offerings often have lower flotation costs (Hansen, 1988). In addition, a standard firm commitment offering can redistribute voting rights and reduce monitoring, whereas there need not be a redistribution of voting rights in a rights offering. Still, as argued by Eckbo and Masulis (1992), if shareholders are expected to sell their rights, then information asymmetry and adverse selection costs become important, and returns could be substantially negative. Indeed, Holderness and Pontiff (2016) find more negative stock market reactions for bigger wealth transfers between participating and non-participating shareholders. Outside of the U.S., rights offerings can also result in substantially negative market reactions, for example in the U.K. (Slovin, Sushka, and Lai, 2000), the Netherlands (Kabir and Roosenboom, 2003), Hong Kong (Ching, Firth, and Rui, 2006), and New Zealand (Marsden, 2000). Still, heterogeneity remains, as Bigelli (1998), for example, finds positive wealth effects for rights issues in Italy. Our analysis can shed light on the overall distinguishing effect of rights issues on announcement returns, and we will separately examine the effects in the U.S., where rights offerings are scarcer.

\subsection{Private issues}


Many recent security issues are privately placed. In fact, Chen, Dai, and Schatzberg (2010) and Floros and Sapp (2012) show that the private placement market has surpassed the traditional seasoned equity market, both in terms of number of annual transactions and total annual issue volume. Issuing a security privately could have implications for announcement effects. Wruck (1989) argues that private placements are purchased by investors who are willing to actively monitor management, which could improve the efficiency of the firm, and would predict more positive announcement effects. Positive announcement effects may also follow from a certification hypothesis, in which informed investors certify the quality of the firm by buying a large fraction of stock in the private placement (Hertzel and Smith, 1993). However, Barclay, Holderness, and Sheehan (2007) argue that securities are mostly privately placed so that management can select so-called friendly investors, who are unlikely to oppose management. If entrenchment is the rationale for most private placements, then this is less likely to be welcomed by non-participating shareholders, and announcement effects are expected to be negative. Private placements are also typically issued with a substantial offering discount, which would also lead to negative price effects.

Empirically, most studies find positive announcement effects for privately placed security issues. More specifically, positive announcement effects for private placements in the United States are reported by, for example, Wruck (1989), Hertzel and Smith (1993), and Barclay, Holderness, and Sheehan (2007). Moreover, Ching, Firth, and Rui (2006) find positive effects in Hong Kong. We will examine whether our meta-analysis can indeed show that private placements are accompanied by significantly different abnormal returns than public placements, and we will again examine this effect separately for the United States.

\subsection{SEOs with warrants included}

Seasoned equity offerings regularly include warrants, also known as unit offerings. A warrant allows an investor to purchase additional numbers of the underlying common stock at a fixed price, until the warrant expires. A reason for including a warrant could be related to sequential financing (Schultz, 1993; Mayers, 1998). In that rationale, warrant offerings provide opportunities for multistage financing settings in which agency costs are reduced, in that the latter stages of the project can only be financed when the firm performed well and the warrants will be exercised. Chemmanur and Fulghieri (1997) argue that warrants can be issued by high quality firms to signal information. Consistent with information signaling, Byoun and Moore (2003) find that warrant issuing firms have relatively high managerial ownership. They predict that firms with warrants in their SEOs experience higher abnormal 
stock returns than if they had issued shares alone. Byoun (2004) reports less negative price reactions to unit offering announcements relative to stock offering announcements.

\subsection{Asymmetric information}

The pecking order model (Myers and Majluf, 1984; Myers, 1984) predicts that because of informational asymmetry between managers and shareholders, equity issues are perceived as bad news. That is, the market assumes that managers try to maximize the wealth of their existing shareholders and an equity issue signals that the new shareholders might pay too high a price. As such, an equity issue is predicted to be associated with a negative abnormal return. In a theory of market timing (Baker and Wurgler, 2002), firms issue equity opportunistically when it is overpriced. Also, according to that theory, seasoned equity issues will be accompanied by negative announcement returns. The signal provided by

an equity issue is especially relevant when informational asymmetry is large. As such, more negative announcement effects can be expected when a firm with high informational asymmetry announces to issue equity.

In this context a meta-analysis is useful as there is no consensus on how to empirically measure information asymmetries. Measures by earlier studies include firm size (Frank and Goyal, 2003), economic conditions (Choe, Masulis, and Nanda, 1993; Salamudin, Ariff, and Nassir, 1999), levels of communication (Ang and Cheng, 2011), quality of accruals (Lee and Masulis, 2009), institutional ownership (Gao and Mahmudi, 2008), and measures based on market microstructure (Bharath, Pasquariello, and $\mathrm{Wu}, 2009)$.

\subsection{Insider trading}

Several studies, starting with Lee (1997), study whether firms that had insiders trading shares before the SEO announcement were associated with lower abnormal returns. If companies issue overvalued stock, as argued by Myers and Majluf (1984), then managers might sell their own (overvalued) shares before an SEO. Clarke, Dunbar, and Kahle (2004) find that U.S. managers issuing equity sell their shares before the SEO announcement. Ching, Firth, and Rui (2006) study the same phenomenon for Hong Kong and find similar results. Gokkaya and Highfield (2014) revisit this topic for the U.S. and find that SEO announcements are negatively related to trades by executive insiders but are unrelated to trades by nonexecutive insiders. 


\subsection{Financial companies and utilities}

Smith (1986) notes that utilities are more likely to issue external capital than industrial companies, which perhaps means that for utilities issue announcements should have had less negative stock price reactions than for industrial companies. Financial companies face explicit capital adequacy regulations, which could also indicate that their equity issues should not lead to strong declines in share prices. In fact, Furlong and Keeley (1989) argue that by issuing additional common stock a financial institution reduces the incentive of bank managers to increase asset risk and increases the size of the cushion available to absorb losses. On the other hand, banks are also often considered opaque (Krishnan, Ergungor, Laux, Singh, and Zebedee, 2010), which could lead to more negative announcement effects.

\subsection{Dividend paying stocks}

According to the free cash flow theory (Jensen, 1986), particularly negative announcement effects can be expected when mature, dividend-paying firms issue new securities. For growth firms, that typically do not pay dividends, security issues are likely to be essential for their growth, whereas for mature firms there is the threat of overinvestment. On the other hand, it could be argued that dividend-paying firms have lower information asymmetry, which would result in more positive announcement effects than for non-dividend-paying firms. Loderer and Mauer (1992) find empirically for a U.S. sample that the market reacts more negatively for issues of dividend-paying firms. For a more recent period, however, Booth and Chang (2011) find more favorable announcement effects for dividend-paying firms.

\subsection{SEOs following recent IPOs}

One reason why IPOs might be underpriced, according to Aggarwal, Krigman, and Womack (2002), is that owner-managers of IPO firms do not maximize the offering prices of IPOs, but rather strategically set low offering prices to be able to create momentum and sell more shares at higher prices through follow-on offerings. Zhang (2013) and Jiang, Stohs, and Xie (2013) find that returns around follow-on offering announcements are more negative for newly public firms than older firms. Potential explanations include differences in information asymmetry, firms trying to take advantage of windows of opportunities, or that a follow-on offering after the IPO signals that the original owners want to exit after a potential lockup period. 


\subsection{Secondary shares SEOs}

Asquith and Mullins (1986) argue that secondary offerings may be viewed by the market as unfavorable signals about a firm's current and future performance. Seasoned offerings of secondary shares may also signal that informed firm insiders are trying to sell their overpriced equity during the "window of opportunity". Based on these two effects, it can be expected that the market would react more negatively to the announcements of secondary offerings than to the announcements of primary offerings. While Lee (1997), Clarke, Dunbar, and Kahle (2004), and Bradley and Yuan (2013) find that the market reaction to the SEO announcements is negative, they do not find significant differences in the market reactions between primary and secondary offerings.

\subsection{Dual-class firm SEOs}

Dual-class firms have two classes of stocks: publicly traded shares with one vote per share and nonpublicly traded shares with multiple votes per share. Smart, Zutter, and Megginson (2008) point out that signaling and agency theories predict different market reactions to single- and dual-class SEO announcements. The signaling theory predicts a more negative market reaction to single-class SEOs as those dilute voting rights at a faster rate. Therefore, they are more likely to signal overvaluation than SEOs of dual-class firms. The agency theory suggests that the more negative market reaction to dualclass SEOs can be explained by the larger differences between the interests of managers and shareholders following an SEO. Smart et al. (2008) find no significant difference in announcement returns between single- and dual-class firms. On the other hand, Gokkaya and Roskelley (2013) find less negative announcement returns for a sample of U.S. dual-class firms.

\subsection{Reasons for offering}

Corporations can issue securities to finance capital expenditures, but also for refinancing purposes. In addition, securities can be issued for general corporate purposes, or even simply to time the market. These different reasons for obtaining financing could affect the announcement returns of the proposed issue. In well-governed firms, the market expects managers to invest in positive NPV projects. Walker and Yost (2008) find that seasoned equity issuers stating specific investment plans experience higher 
announcement returns. The market might perceive stated capital expenditure purposes as a credible signal of profitable investment opportunities. Refinancing debt with equity might not typically lead to the best announcement returns, as most firms are already underlevered and fail to fully exploit the tax shield provided by debt financing (Graham, 2000).

\subsection{Differences in corporate governance systems}

We also consider country-specific characteristics. Our analysis incorporates studies from around the world, and circumstances differ across countries. Moerland (1995) proposes two categories of corporate systems that may have an impact on economic events: market-oriented systems and network-oriented systems. Market-oriented systems (also called Anglo-Saxon systems) have well-developed financial markets and active markets for corporate control, with many firms listed on stock exchanges. Countries with market-oriented systems include the United States, United Kingdom, Canada, Australia, and New Zealand. Network-oriented systems typically have closely held corporations, including family ownership structures, state ownership, and group membership of corporations. Banks can be highly involved in decision making in network-oriented systems. Countries included in the network-oriented systems are Germanic countries (Germany, Switzerland, Austria, and the Netherlands), Latinic countries (Italy, Spain, France, and Belgium), and Japan. Our meta-analysis will investigate whether differences in corporate governance systems are related to differences in abnormal returns. As an alternative corporate governance classification, we follow La Porta, Lopez-de-Silanes, Shleifer, and Vishny (1997), who present a classification based on investor protection levels. Table II of their paper groups countries into high- and low-protection categories.

As a significant proportion of studies of the announcement effects of equity issues are based on the U.S. data, we separately add a dummy variable indicating whether the analysis is based on U.S. firms. In the end, our analysis allows us to examine the differences between the U.S., other market-oriented systems, and network-oriented systems. Given that corporate governance systems change over time, most notably after the accounting scandals in the early 2000s, we also include a post-2000 dummy.

\subsection{Publication Bias}

An interesting aspect of our study is that we can shed some light on whether there is a publication bias. Potentially, papers with stronger results are more likely to end up in the well-known journals. There could also be a quality bias but calculating wealth effects is not extremely complex and it is not obvious 
that poorly-executed studies would systematically over- or underestimate wealth effects. We include dummy variables that identify studies published in one of the Top 4 finance journals (Journal of Finance, Journal of Financial Economics, Review of Financial Studies, and Journal of Financial and Quantitative Analysis) and in one of the Top 38 finance journals. These are the 26 journals as identified by Heck and Cooley (2009) with the addition of Accounting and Finance, Critical Finance Review, European Financial Management, International Review of Finance, International Review of Financial Analysis, Journal of International Financial Markets, Institutions and Money, Journal of International Money and Finance, European Journal of Finance, Journal of Business, Review of Asset Pricing Studies, Review of Corporate Finance Studies, and Review of Finance.

\section{Meta-analysis model}

\subsection{Meta-analysis}

We use meta-analysis to review papers on wealth effects associated with seasoned equity offerings. Traditionally, review papers in finance use a narrative literature review. ${ }^{5}$ Meta-analysis is an alternative for these narratives. Meta-analysis uses quantitative methods to summarize and analyze research literature. It treats a study as a unit of analysis and it is entirely based on quantitatively expressed study attributes and outcomes (Green and Hall, 1984). An important advantage of meta-analysis is that it is possible to derive statistically strong conclusions from the collected empirical evidence. In addition, the results are more objective compared to narrative literature overviews.

\subsection{Model}

The input in our meta-analysis are the studies reviewed in Table 2 that measure the wealth effects associated with seasoned equity offerings. These wealth effects are measured as abnormal returns using different methods that include mean adjusted returns, market adjusted returns, Capital Asset Pricing Model (CAPM) returns, matched or control portfolio returns, and market model returns. ${ }^{6}$ The abnormal returns from previous studies are used as observations in a multi-factor natural experiment, with the experimental factors corresponding to the factors hypothesized to influence wealth creation (Datta,

\footnotetext{
${ }^{5}$ See, for example, Eckbo, Masulis, and Norli (2007) as well as other review papers in the book of Hansen, Ritter, and Xu (2007).

${ }^{6}$ In case a study uses more than one method to calculate abnormal returns, we only use the results for the more conventional method, i.e. the market model. However, very few studies report results for more than one method.
} 
Pinches, and Narayanan, 1992, page 71). ${ }^{7}$ The form of meta-analysis that we use is generally referred to as replication analysis.

The dependent variable is the abnormal return, as a proxy for wealth creation. Out of 199 studies, 77 studies reported CAR over a $(-1,1)$ event window, 54 studies used a $(-1,0)$ window, 37 studies used a $(0,1)$ window, 8 studies used a $(0,0)$ window, one study reported a $(-2,0)$ window, and the remaining studies reported event windows longer than 3 days. To capture differences that can be attributed to duration of event windows, we (i) do a robustness check by normalizing the reported CARs by dividing them by the number of days in the event window and (ii) introduce dummy variables for observations with different event windows.

The values of the dependent variable (CAR) and the independent variables in the regressions are based on the results of sub-samples reported by the primary studies. The independent variables in the regressions are dummy variables that are coded based on the sub-sample separation criteria reported in individual studies. For example, a study may present abnormal returns for separate sub-samples of rights issues and private issues. In this case, we would assign the variable Rights issue a value of one to the sub-sample of rights issues and a value of zero to the sub-sample of private issues. Conversely, we would assign a value of one for the variable Private issue for the sub-sample of private issues while for the sub-sample of rights issues the value of this variable would be set to zero. If another study did not report separate sub-samples of rights and private issues, then the values of both Rights issue and Private issue for such a study would be set to zero. The possibility that there are actually some rights and private issues in the sub-samples that are set to zero leads to the possibility of underestimating the effects of these variables and in general works against us in finding significant effects of the independent variables. The relation between dependent and independent variables can be described as:

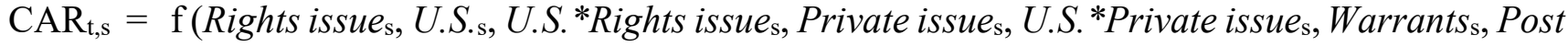
2000 sample $_{\mathrm{s}}$, U.S. *Post 2000 sample $_{\mathrm{s}}$, Low asymmetric information $\mathrm{s}$, Insider $\mathrm{s}_{\mathrm{s}}$ Industrial Company, Financial Company $_{\mathrm{s}}$, Dividend paying stock, $\mathrm{s}_{\mathrm{s}}$ SEO within 3 yrs of IPO $\mathrm{s}_{\mathrm{s}}, \mathrm{SEO}$ for debt reduction, SEO for investment $t_{\mathrm{s}}$,Dual-class firm SEO , Secondary $S E O_{s}$, Network-oriented country, Medium and low investor protection $_{\mathrm{s}}$, Top 4 journal $_{\mathrm{s}}$, Top 38 journal $_{\mathrm{s}}$ 2-day event windows, Event window other than 2day or $\left.3-d a y_{s}\right)$

Where:

\footnotetext{
${ }^{7}$ Other studies that have used this type of analysis include Veld and Veld-Merkoulova (2009) for corporate spin-offs and Abdul Rahim, Goodacre, and Veld (2014) for convertible bond and warrant-bond offerings.
} 


\section{Different forms of SEO placement}

Rights issues

Private issue
$=$ issue is defined in the original paper as rights issue $(1=\text { Yes })^{8}$;

$=$ issue is defined in the original paper as private issue $(1=\mathrm{Yes})$;

\section{Issuer characteristics}

Warrants

Post 2000 samples

Low asymmetric information

Insider

Dividend paying stocks

SEO within 3 yrs of IPOs

Dual-class firms $S E O_{\mathrm{s}}$

Secondary SEOss
$=$ issue is defined in the original paper as an equity issue that includes warrants $(1=$ Yes $)$;

$=$ study using issues from after the year $2000(1=\text { Yes })^{9}$;

$=$ issue by a company with a measure of low asymmetric information $(1=\mathrm{Yes})^{10}$;

$=$ issue with a presence of insider information and/or a high level of insider trading prior to the SEO announcement $(1=$ Yes $)$;

$=$ issue by a dividend-paying company $(1=$ Yes $)$;

$=\mathrm{SEO}$ is issued within 3-year period of IPO $(1=\mathrm{Yes})$;

$=$ SEO is issued by dual-class firm $(1=\mathrm{Yes})$;

$=$ SEO with secondary shares offered $(1=$ Yes $)$;

\section{Issuer type}

Industrial Companys $\quad=$ industrial company $(1=\mathrm{Yes})$;

Financial Company $y_{s} \quad=$ financial company $(1=$ Yes $)$;

\section{Reasons for offering}

SEO for debt reduction s $_{S} \quad=$ funds are used for refunding old debt $(1=\mathrm{Yes})$;

SEO for investment $\quad \quad=$ funds are used for capital expenditures $(1=\mathrm{Yes})$;

\section{Differences in corporate governance systems}

\footnotetext{
${ }^{8}$ U.K. open offers and U.K. placings are classified as non-rights issues; Rights issue dummy for these observations is set equal to zero.

${ }^{9}$ Only studies or samples that start in the year 2000 or later are assigned a dummy variable of one. If a reported sample spans the year 2000, for example 1997-2003, the dummy variable is set to zero. However, our results are robust if we classify the latter as post 2000 (i.e., if we assign a value of one for such studies and/or samples).

${ }^{10}$ As mentioned in Section 3.4, this variable is measured differently in individual studies. We have followed the original studies and we assign a value of one for Low asymmetric information following their specific proxy. For example, if a study defines a sub-sample with "high quality of accruals" as the "low asymmetric information" sub-sample, then we assign a value of one for the dummy variable. Similarly, if another study uses "high institutional ownership" sub-sample as the proxy for the low information asymmetry sub-sample, we assign a value of one for the dummy variable for that sub-sample. Therefore, the low information asymmetry dummy is based on different variables that proxy low levels of information asymmetry.
} 
Network oriented countrys $=$ network-oriented economy as defined by Moerland (1995) $(1=$ Yes);

Medium and low protection s $_{\text {s }}=$ economy with medium or low level of investor rights protection as per La Porta, Lopez-de-Silanes, Shleifer, and Vishny (1997) (1 = Yes);

U.S.s $=$ study on the United States $(1=$ Yes $)$;

\section{Publication bias}

Top 4 journals

Top 38 journals
$=$ study is published in one of the Top 4 finance journals, i.e. Journal of Finance, Journal of Financial Economics, Review of Financial Studies, Journal of Financial and Quantitative Analysis (1 = Yes);

$=$ study is published in one of the Top 26 finance journals as defined by Heck and Cooley (2009) plus Accounting and Finance, Critical Finance Review, European Financial Management, International Review of Finance, International Review of Financial Analysis, Journal of International Financial Markets, Institutions and Money, Journal of International Money and Finance, European Journal of Finance, Journal of Business, Review of Asset Pricing Studies, Review of Corporate Finance Studies, and Review of Finance (formerly European Finance Review).

\section{Reported event window}

2-day event windows $=$ study sample reports CAR over a two-day event window $(1=$ Yes $)$; Event window other than 2-day or 3-days

$=$ study sample reports CAR over an event window that is neither 2day or 3-day $(1=$ Yes $)$;

\section{Results of the meta-analysis}

The 199 studies summarized in Table 2 provide the data for the meta-analysis. In our main models we use all sub-samples that report a mean CAR for an event window containing the seasoned equity offering announcement day. Many of these studies present separate sub-samples involving analysis of at least one of the variables mentioned in Section 3, leading to 861 (sub)samples that we can employ. The mean and median cumulative abnormal returns from these 199 studies are included in Table 3. 
The total number of SEO announcements within the 861 sub-samples is 529,990 . However, there is a large amount of double counting involved, because many studies present both results for the total sample and results for sub-samples. After eliminating this double-counting, we are left with 275,103 observations. Even this number still includes substantial double counting, because the same observation for a specific seasoned equity offering is likely to be included in multiple studies (this phenomenon especially occurs for observations in U.S. studies).

The mean CAR across full samples of the 199 studies is $-0.98 \%$, and it is significantly different from zero at the $1 \%$-level. The mean CAR reported in the 161 journal articles is $-0.86 \%$, and the mean CAR reported in the 37 working papers is $-1.51 \%$; both are statistically different from zero at the $1 \%$ level. The difference between the two samples is significant at the $10 \%$-level. The proximity of the mean to the median $(-1.39 \%)$ for all studies suggests that the results are not likely to be driven by outliers. The most negative abnormal return reported in a study is $-12.82 \%$ and the most positive abnormal return is $21.1 \%$. The Kruskall-Wallis test rejects the null hypothesis that the samples of CARs reported in journal articles and working papers come from identical populations with $95 \%$ confidence. ${ }^{11}$

While the simple mean CAR may indicate the size of the reaction of the stock prices to the SEO announcements, it ignores different levels of precision employed in individual studies. The precision of the CARs reported in studies is manifested by their standard errors, which, in turn, are influenced by sample sizes. To account for the differences in sample sizes and reported standard errors, we also employ the random-effect meta-analysis approach summarized in Borenstein, Hedges, Higgins, and Rothstein (2009). More specifically, we use the DerSimonian and Laird (1986) estimator to calculate the summary effect (i.e., weighted average CAR). The DerSimonian and Laird (1986) estimation uses standard errors of the CARs reported in individual studies for calculating the relative weight for each study. The reported summary effect is based on the analysis of CARs from the 96 studies that report standard errors for their CARs. Based on this methodology, the estimate of the CAR associated with the SEO announcement is equal to $-1.08 \%$ (untabulated) and is statistically different from zero ( $z$ statistic is equal to -7.66 ) with the $95 \%$ confidence interval ranging from $-1.36 \%$ to $-0.80 \%$.

We continue our analysis with a meta-regression. While there are 861 sub-samples reported in the primary studies, some studies report both full sample results and results for sub-samples. To deal with the problem of double counting in our regression analysis we exclude 100 observations reporting full

\footnotetext{
${ }^{11}$ We checked for possible differences between studies that present 2-day, 3-day, and other event windows. The average CARs for studies reporting 2-day and 3-day windows are $-1.41 \%(t$-statistics $=-5.49)$ and $-0.88 \%(t$-statistics $=-2.46 \%)$ respectively. The average CAR for studies using other event windows is $-0.13 \%(t$-statistics $=-0.35)$.
} 
sample results if the full sample is entirely incorporated in the sub-samples from our regressions. Furthermore, we exclude 16 sub-samples from international studies to be able to examine how measures for institutions from individual countries affect the wealth effects. This procedure leaves us with 745 sub-samples reporting CARs, 448 of which report $t$-statistics of CARs. To correct for potential correlation between results reported for the same country, we use Rogers (1983) clustered standard errors with country as a cluster as suggested by Petersen (2009). Table 4 shows the results. ${ }^{12}$

[Please Insert Table 4 here]

Panel A includes the results for all countries. All models are based on the mean CAR as the dependent variable. In Model 1, the coefficient for Rights issue is negative and significant at the 5\%level. Hence, rights issues are associated with more negative announcement effects than other offerings, all else equal. Interestingly, the interaction term of Rights issue and U.S. has a positive coefficient that is significant at the $1 \%$-level, and the size of this coefficient suggests that rights issues in the U.S. are associated with more positive announcement effects than public offerings. Right issues thus mostly reduce wealth effects outside the United States. Strikingly, the isolated effect of the U.S. dummy is strongly negative. As such, public offerings in the U.S. are associated with substantially more negative wealth effects than public offerings in other countries, all else equal. This result is in line with Table 2, where we can see that most U.S. studies present negative abnormal returns, while the result for other countries is mixed. These findings highlight the heterogeneity across countries and imply that studying the institutional specifics of rights offerings can be important (Balachandran, Faff, and Theobald, 2008).

The effect of Private issue is positive and significant at the 1\%-level, which is in line with the results of individual studies on this effect as documented in Section 3.2. The effect does not seem to be driven by U.S. studies, since the interaction term for Private issue and U.S. is not statistically significant. We do not find a significant effect for the Post 2000 sample. Contrary to predictions of the pecking order theory, the coefficient for Low asymmetric information is not significant. Similarly, the result for Insider is not significant.

In Model 1, seasoned equity offerings by industrial companies seem to be associated with significantly different abnormal returns from SEOs by utilities in the sense that industrial companies

\footnotetext{
12 We perform two robustness checks. In the first robustness check, we use the CARs from the studies that use only a 2- or 3-day event window. In the second check, we perform a regression analysis only using studies reporting 2-day event windows. The findings from both robustness checks do not materially differ from the findings presented in this paper. Detailed results are available from the authors on request.
} 
are associated with more negative abnormal returns. This result is in line with the reasoning of Smith (1986) who argues that utilities have more need for external capital and therefore their security issuance announcements are likely to be associated with less negative abnormal returns.

The coefficient for SEO within 3 yrs of IPO is significantly negative at the $1 \%$-level. We find that if a seasoned equity offering is used to pay back debt, the announcement return is more negative. This result is consistent with firms leaving money on the table by not fully exploiting the debt tax shield (Graham, 2000). An alternative explanation, suggested by Hertzel and Li (2010), is that SEOs that are used to decrease long-term debt can often be contributed to overvaluation. There is no significant effect if the SEO is used for investment purposes. The coefficient for Secondary share SEO is negative and is significant at the 1\%-level. This result is in line with the reasoning of Asquith and Mullins (1986) that secondary offerings may be viewed by the market as unfavorable signals about the current and future performance of the company that makes the announcement.

Finally, we find that if the paper is published in a Top 38 journal, the abnormal return is more positive. However, this coefficient is only significant at the $10 \%$-level. This result is slightly different from the finding in Table 3 where we also did not find a significant difference between CARs reported in published papers and SSRN-working papers.

In Model 2 we add the variable Network-oriented country. This variable is not significant. The coefficients of the other variables largely remain the same. Importantly, none of the significance levels changes.

Model 3 is the same as Model 2 except that the variable for Network-oriented country is replaced by High investor protection. The coefficient for this variable, which is based on country classification by La Porta, Lopez-de-Silanes, Shleifer, and Vishny (1997), is not significant. The coefficients of the other variables do not change much compared to Model 2. There are some minor changes between the significance levels of different variables. The major exceptions are the fact that the variable for Warrants is now significantly positive at the $10 \%$-level, and that the variables for Dividend paying stock and SEO for debt reduction are no longer significant.

Model 4 is the same as Model 1, except that we add a second variable for the publication bias by adding Top 4 journal to the model. This variable is significantly positive at the $1 \%$-level. This result suggests that, on average, CARs reported in papers published in Top 4 journals are statistically different from CARs reported in papers published in other journals and in working papers. All four models provide good explanatory power, with the adjusted $\mathrm{R}^{2}$ being at least $25 \%$.

Given the dominance of U.S. studies in our sample, we also separately present results for the U.S. studies. These results are included in Panel B of Table 4. As can be predicted from the results for the 
interaction term between Rights issue and U.S. in Panel A, the Rights issue variable is significant in Model 5 of Panel B. The coefficient for Private issue is significantly positive, in line with the results for the entire sample in Models 1 to 4 . Insider is now significantly negative, which is in line with what one would expect: if insiders trade before the SEO announcement, the wealth effects will be lower. The coefficients for Industrial Company and SEO for debt reduction are the same as in Model 1, but they are now all significant at the 1\%-level. The variables for Dividend paying stock and SEO within 3 yrs of IPO were significant in Model 1 for the entire sample, but they are not significant for the U.S. studies.

Model 6 is the same as Model 5, except that we add a variable for publication bias (Top 4 journal). In line with the total sample (see Model 4), this variable is significantly positive, indicating that there may be a publication bias for papers on the United States published in Top 4 journals. The significance levels of the other coefficients remain the same between Models 5 and 6.

Panel C includes the results for the non-U.S. studies. Given the results of Panel A and Panel B, the results for Panel C are not surprising. For example, Rights issue has a significantly negative coefficient. The variables Industrial Company and Dividend paying stock that were significant in Model 1 are no longer significant. Given the heterogeneity in the results of the countries outside the United States, it is probably difficult to find systematic patterns for these countries. Model 8 again adds another variable for publication bias (Top 4 journal). This variable is significantly positive as in Models 4 and 6, but adding this variable does not change any of the coefficients compared to Model 7.

A potential limitation with our analysis is that we use different windows, i.e. 2 days, 3 days, and other windows, for the dependent variable. We try to alleviate this concern in Table 4 by adding control variables for 2-day event window and for Event window other than 2-day or 3-day. These variables are meant to control for the effect of having different event windows. ${ }^{13}$

A meta-analysis depends on the reliability of the CARs reported in earlier studies. As indicated before, the reliability of these CARs depends on the sample sizes of the original studies. The sample size of the studies that we include varies considerably. The largest study included in the analysis in Table 4 contains 7,720 observations (Intintoli and Kahle, 2010) and the smallest study only contains 19 observations (Wansley and Dhillon, 1989). ${ }^{14}$ Also, the variability of the mean CARs varies substantially between different studies that cover different time periods and countries. Following Nelson and Kennedy (2009), Abdul Rahim, Goodacre, and Veld (2014) suggest an alternative measure

\footnotetext{
${ }^{13}$ We also ran a separate regression in which we use daily average CARs as the dependent variables. In these regressions we divide the CARs by the number of days in the event window. The results from these regressions are largely the same as the results in Table 4. Differences are mainly in minor changes in significance levels. These results are available on request from the authors.

${ }^{14}$ The study of Massa, Vermaelen, and Xu (2013) in Table 2 contains more observations $(12,639)$ than the study of Intintoli and Kahle (2010), but international studies are not included in the meta-regressions reported in Table 4 and Table 5.
} 
that considers reliability. They use the $t$-statistics (or $z$-statistics) derived from each study's mean CAR and its standard error instead of abnormal returns. This approach solves the problem of heteroskedasticity of effect-size variances. Following this methodology, we use $t$-statistics as an alternative proxy for wealth effects using all sub-samples for which the measure can be derived but ignoring sub-samples from international studies and full sample data if it is fully incorporated in subsamples. This restriction reduces the sample size to 448 observations. The results of this analysis are included in Table 5.

[Please Insert Table 5 here]

The most important results of Panel A of Table 4 are also found in Panel A of Table 5. For example, the Rights issue coefficient is now only significant at the 10\%-level (in three out of the four model specifications), but the interaction term between this variable and U.S. (U.S. *Rights issue) is again positive and significant at the 1\%-level. Panels B and C confirm this result, because Rights issue is both positive and significant for the United States and negative and significant for the non-U.S. studies. The coefficient for Private issue is again significant (in two out of the four model specifications), but now the interaction term with U.S. is also significantly positive. This result is confirmed in Panel B where the coefficient is significantly positive at the $1 \%$-level for the U.S. results. The Warrants variable is significant for the entire sample in all four model specifications. Given that it is also positive and significant for the U.S.-sample (at the 1\%-level), it is reasonable to assume that this result is driven by the U.S. studies.

The coefficient for Post 2000 sample is not significant for the entire sample. This result is in line with Table 4. However, it is now positive and significant for the U.S. sub-sample (see Models 5 and 6). Also, the interaction term between U.S. and Post 2000 sample is now positive and significant at the 1\%-level. This finding means that U.S. studies show less negative abnormal returns from the year 2000. It also highlights the relevance of changes over time, and suggests the importance of macro-economic variables (Choe, Masulis, and Nanda, 1993).

In line with Table 4, the variable for Insider is still not significant. However, when we look at the U.S. sub-sample, we see that the coefficient for this variable changes from negative and significant in Table 4 to positive and significant in Table 5, but only for one of the two models. This result is surprising, because we would have expected it to be negative based on the review of the previous studies. In Table 5 Insider is significantly negative outside the U.S. This result is more in line with our a priori expectations. 
In line with Table 4 the coefficient for Industrial Company is negative and significant. The coefficient for Financial Company was not significant in all eight specifications in Table 4. However, this coefficient is positive and significant at the 5\%-level in Table 5 for the sample of all studies (Models 1 to 4). This variable is also positive and significant for the U.S. sub-sample. The significantly positive coefficient for this variable is in line with a study by Li, Liu, and Siganos (2016), who find that convertible bond offers by commercial banks are associated with higher abnormal returns than convertible bond issues by other companies.

The differences between Table 4 and 5 highlight the potential relevance of how to control for sample sizes. Also, the differences between the tables may be driven by differences in standard errors across countries and sample periods. The coefficient for U.S. is still negative and significant at the $1 \%$-level for all models.

A further important difference between Tables 4 and 5 is in the coefficient for SEO for debt reduction. The coefficient for this variable is negative and significant for the U.S. sample in Table 4 and is positive and significant at the 1\%-level in Table 5. SEO for investment is not significant in Panel A of Table 4, but is positive and significant at the 1\%-level in all specifications in Table 5.

A note of caution is in place for the results in Table 5. Given that we only have $t$-statistics for 448 out of the original 745 observations, the results in Table 5 might be less representative than those in Table 4.

\section{Discussion of the results, conclusions, and future research directions}

This paper presents the results from a meta-analysis of 861 sub-samples from 162 studies of wealth effects of seasoned equity offerings published in a list of 38 influential finance journals and from 37 working papers on SEO wealth effects retrieved from SSRN. Several interesting findings emerge from our study. We find that seasoned equity issues by U.S. companies are associated with lower abnormal returns than offers in other countries. U.S. rights issues are associated with less negative abnormal returns, but rights issues outside the U.S. are associated with more negative abnormal returns. Private placements are associated with a less negative market reaction. Other important determinants of SEO wealth effects include whether the issuer pays dividends, and the stated uses of proceeds of the offerings. Abnormal returns in studies published in the Top-4 journals are less negative than those in other publications, all else equal.

Even though the topic of abnormal returns associated with seasoned equity issues has been studied in detail, there is still more work to be done. For one thing, this topic confirms the home bias that 
Karolyi (2016) documented. This bias refers to the fact that, even after considering the size of the U.S. stock market compared to other markets, there is a disproportional number of studies based on U.S. data. We find 199 studies on announcement effects associated with seasoned equity offerings of which no less than 131 are on the U.S. Therefore, there seems to be a case to study other markets in more detail as well.

Related to the first topic, it would be interesting to study which factors drive the differences between the results for the U.S. and other countries. To some extent they can be explained by corporate governance differences, but it is also possible that other factors play a role. Third, the finding that the interaction term for Rights issue and a U.S. dummy is positive is puzzling in the sense that at the same time we witness an almost complete disappearance of rights issues in the United States. The puzzle gets even bigger if we consider the fact that the direct issuance costs of rights issues are smaller than those of other ways to place equity issues.

Fourth, we don't find overall significance for differences in information asymmetry, while this factor is important in both the pecking order and the market timing models, which are two of the mostoften cited theories on seasoned equity offerings. Perhaps, the fact that information asymmetry is measured using different variables plays a role here. A more systematic study on the relation between seasoned equity offer announcements and various information asymmetry estimates would clarify this topic. Such a study could determine whether the previously used measures for information asymmetry really measure differences in information or whether they also capture other company characteristics.

Finally, some factors show up as significant in our meta-analysis, but they have not been researched extensively. An example is the relevance of the stated use of proceeds. Our results suggest that a further examination of these factors could lead to an even better understanding of the cost of issuing equity. 


\section{References: ${ }^{15}$}

Studies included in the meta-analysis are indicated with a*

Abdul Rahim, N., Goodacre, A., and Veld C., 2014. Wealth effects of convertible bond and warrantbond offerings: A meta-analysis. European Journal of Finance 20, 380-398.

Adler, M., and Shea, N., 2010. Seasoned equity offerings on the Nasdaq: New evidence on the asymmetric information discount. SSRN Working Paper no. 1564164, February.*

Aggarwal, R., Krigman, L., and Womack, K., 2002. Strategic IPO underpricing, information momentum, and lockup expiration selling. Journal of Financial Economics 66, 105-137.

Aggarwal, R., and Zhao, X., 2008, Significant issuance date returns in seasoned equity offerings: An options-based resolution of a puzzle. International Review of Financial Analysis 17, 793-804.*

Akhigbe, A., and Madura, J., 2001. Motivation and performance of seasoned equity offerings by closedend funds. Financial Review 36, 101-122.*

Akhigbe, A., Newman, M., and Safieddine, A., 2006. Market expectations and the valuation effects of equity issuance. Journal of Financial Research 29, 253-269.*

Akhigbe, A., and Whyte, A.M., 2015. SEO announcement returns and internal capital market efficiency. Journal of Corporate Finance 31, 271-283.*

Altinkilic, O., and Hansen, R.S., 2003. Discounting and underpricing in seasoned equity offers. Journal of Financial Economics 69, 285-323.*

Anderson, H.D., Rose, L.C., and Cahan, S.F., 2006. Differential shareholder wealth and volume effects surrounding private equity placements in New Zealand. Pacific-Basin Finance Journal 14, 367-394.*

Ang, J., and Cheng, Y., 2011. The endogeneity of information asymmetry and corporate financing decisions. Journal of Financial Research 34, 411-440.*

Armitage, S., 2002. Do underwriters certify value? Evidence from UK rights issues and open offers. Journal of Business Finance \& Accounting 29, 1239-1273.*

Armitage, S., 2012. The calculation of returns during seasoned equity offers. European Journal of Finance 18, 393-417.*

Armitage, S., and Capstaff, J., 2009. Comment on 'earnings management around UK open offers'. European Journal of Finance 15, 53-60.*

Asquith, P., and Mullins, D.W., 1986. Equity issues and offering dilution. Journal of Financial Economics 15, 61-89.*

\footnotetext{
15 The reference list is up-to-date per December 31, 2017. It is possible that in the meantime some forthcoming papers have appeared in print and/or that some working papers have been accepted for publication. However, to keep a one-to-one correspondence between Table 2 and the reference list, we have not updated the references after December $31,2017$.
} 
Autore, D., and DeLisle, R. J. (2016). Skewness preference and seasoned equity offers. Review of Corporate Finance Studies, 5 (2), 39.*

Autore, D.M., Hutton, I., and Kovacs, T., 2011. Accelerated equity offers and firm quality. European Financial Management 17, 835-859.*

Autore, D.M., Kumar, R., and Shome, D.K., 2008. The revival of shelf-registered corporate equity offerings. Journal of Corporate Finance 14, 32-50.*

Baker, M., and Wurgler, J., 2002. Market timing and capital structure. Journal of Finance 57, 1-32.

Balachandran, B., Faff, R., and Theobald, M., 2008. Rights offerings, takeup, renounceability and underwriting status. Journal of Financial Economics 89, 328-346.

Barclay, M.J., Fu, F., and Smith, C.W., 2012. Rational financial management: Evidence from seasoned equity offerings, SSRN Working Paper no. 1099850, March 19.*

Barclay, M.J., Holderness, C.G., and Sheehan, D.P., 2007. Private placements and managerial entrenchment. Journal of Corporate Finance 13, 461-484.*

Barclay, M.J., and Litzenberger, R.H., 1988. Announcement effects of new equity issues and the use of intraday price data. Journal of Financial Economics 21, 71-99.*

Baruch, S., Panayides, M., and Venkataraman, K., 2017. Informed trading and price discovery before corporate events. Journal of Financial Economics 125, 561-588.*

Bayless, M., and Chaplinsky, S., 1991. Expectations of security type and the information content of debt and equity offers. Journal of Financial Intermediation 1, 195-214.*

Bayless, M., and Chaplinsky, S., 1996. Is there a window of opportunity for seasoned equity issuance? Journal of Finance 51, 253-278.*

Berkman, H., McKenzie, M.D., and Verwijmeren, P., 2017. Hole in the wall: Informed short selling ahead of private placements. Review of Finance, 1047-1091.*

Bessler, W., Drobetz, W., Seim, M., and Zimmermann, J., 2016. Equity Issues and Stock Repurchases of Initial Public Offerings. European Financial Management 22, 31-62.*

Bhagat, S., Marr, W., and Thompson, G.R., 1985. The rule 415 experiment: Equity markets. Journal of Finance 40, 1385-1401.*

Bharath, S.T., Pasquariello, P., and Wu, G., 2009. Does asymmetric information drive capital structure decisions? Review of Financial Studies 22, 3211-3243.

Bigelli, M., 1998. The quasi-split effect, active insiders and the Italian market reaction to equity rights issues. European Financial Management 4, 185-206.*

Billett, M.T., Elkamhi, R., and Floros, I.V., 2015. The influence of investor identity and contract terms on firm value: Evidence from PIPEs. Journal of Financial Intermediation 24, 564-589.* 
Billett, M.T., Floros, I.V., and Garfinkel, J., 2018. At the market (ATM) offerings. Journal of Financial and Quantitative Analysis, forthcoming.*

Bohren, O., Eckbo, B.E., and Michalsen, D., 1997. Why underwrite rights offerings? Some new evidence. Journal of Financial Economics 46, 223-261.*

Boone, A.L., Floros, I.V., and Johnson, S.A., 2016. Redacting proprietary information at the initial public offering. Journal of Financial Economics 120, 102-123.*

Booth, L., and Chang, B., 2011. Information asymmetry, dividend status, and CEO announcement-day returns. Journal of Financial Research 34, 155-177.*

Borenstein, M., Hedges, L.V., Higgins, J.P.T., and Rothstein, H.R., 2009. Introduction to metaanalysis, John Wiley \& Sons.

Bradley, D., and Yuan, X., 2013. Information spillovers around seasoned equity offerings. Journal of Corporate Finance 21, 106-118.*

Brisker, E.R., Autore, D.M., Colak, G., and Peterson, D.R., 2014. Executive compensation structure and the motivations for seasoned equity offerings. Journal of Banking \& Finance 40, 330-345.*

Brooks, L.D., Chen, X., and Yu, T., 2006. Industry screening: Evidence from seasoned equity offerings. SSRN Working Paper no. 722663, December.*

Brous, P.A., and Kini, O., 1992. Equity issues and Tobin's Q: New evidence regarding alternative information release hypotheses. Journal of Financial Research 15, 323-339.*

Byoun, S., 2004. Stock performance following seasoned stock-warrant unit offerings. Journal of Business 77, 75-100.*

Byoun, S., and Moore, W.T., 2003. Stock vs. stock-warrant units: Evidence from seasoned offerings. Journal of Corporate Finance 9, 575-590.*

Chan, K., Nayar, N., Singh, A.K., and Yu, W., 2018. Information content of offer-date revelations: A fresh look at seasoned equity offerings. Financial Management, forthcoming.*

Chang, J.J., and Shin, H-H., 2004. The SEC's review of the registration statement and stock price movements during the seasoned equity issuance process. Pacific-Basin Finance Journal 12, 359-386.*

Chaudhuri, R., and Seo, H., 2012. An agency theory explanation of SEO underperformance: Evidence from dual-class firms. Journal of International Financial Markets, Institutions and Money 22, 575588.*

Chemmanur, T.J., and Fulghieri, P., 1997. Why include warrants in new equity issues? A theory of unit IPOs. Journal of Financial and Quantitative Analysis 32, 1-24.

Chemmanur, T.J., Michel, J-S., Nandy, D.K., and Yan, A., 2010. Capital structure and security issuance under heterogeneous beliefs. SSRN Working Paper no. 965923, November 14.* 
Chen, A-S., Cheng, L-Y., Cheng, K-F., and Chih, S-W., 2010. Earnings management, market discounts and the performance of private equity placements. Journal of Banking and Finance 34, 1922-1932.*

Chen, H-C., Dai, N., and Schatzberg, J.D., 2010. The choice of equity selling mechanisms: PIPEs versus SEOs. Journal of Corporate Finance 16, 104-119.*

Chen, X., 2017. Improved corporate governance and Chinese seasoned equity offering announcement effects. Accounting and Finance 57, 401-428.*

Cheng, L.Y., Wang, M.C., and Chen K.C., 2014. Institutional investment horizons and the stock performance of private equity placements: evidence from the Taiwanese listed firms, Review of Pacific Basin Financial Markets and Policies 17(2), 1-30.*

Chikolwa, B., and Kim, J., 2009. Determinants and impact of seasoned equity offerings: The case of A-REITs, SSRN Working Paper no. 1460288, August 21.*

Ching, K.M.L., Firth, M., and Rui, O.M., 2006. The information content of insider trading around seasoned equity offerings. Pacific-Basin Finance Journal 14, 91-117.*

Choe, H., Masulis, R.W., and Nanda, V., 1993. Common stock offerings across the business cycle. Journal of Empirical Finance 1, 3-31.*

Clarke, J., Dunbar, C., and Kahle, K.M., 2001. Long-run performance and insider trading in completed and cancelled seasoned equity offerings. Journal of Financial and Quantitative Analysis 36, 415-430.*

Clarke, J., Dunbar, C., and Kahle, K., 2004. The long-run performance of secondary equity issues: A test of the windows of opportunity hypothesis. Journal of Business 77, 575-603.*

Cline, B.N., Garner, J.L., and Yore A.S, 2014. Exploitation of the internal capital market and the avoidance of outside monitoring. Journal of Corporate Finance 25, 234-250.*

Cooney, J.W., Kato, H.K., and Schallheim, J.S., 2003. Underwriter certification and Japanese seasoned equity issues. Review of Financial Studies 16, 949-982.*

Corby, C.E., and Stohs, M.H., 1998. Investment opportunities and Irish equity offerings. European Journal of Finance 4, 357-367.*

Cornett, M.M., Mehran, H., Pan, K., Phan, M., and Wei, C., 2014. CDS and equity market reactions to stock issuances in the U.S. financial industry: Evidence from the 2002-13 period. SSRN working paper no. 2521615.*

Cronqvist, H., and Nilsson, M., 2005. The choice between rights offerings and private equity placements. Journal of Financial Economics 78, 375-407.*

Dahiya, S., Klapper, L.F., Parthasarathy, H., and Singer, D., 2017. The role of private equity investments in public firms: International evidence. Journal of Corporate Finance 45, 64-83 .*

Dai, N., 2007. Does investor identity matter? An empirical examination of investments by venture capital funds and hedge funds in PIPEs. Journal of Corporate Finance 13, 538-563.* 
Datta, D., Iskandar-Datta, M., and Raman, K., 2005. Executive compensation structure and corporate equity financing decisions. Journal of Business 78, 1859-1890.*

Datta, D.K., Pinches, G.E., and Narayanan, V.K., 1992. Factors influencing wealth creation from mergers and acquisitions: a meta-analysis. Strategic Management Journal 13, 67-84.

de Jong, A., and Veld, C., 2001. An empirical analysis of incremental capital structure decisions under managerial entrenchment. Journal of Banking and Finance 25, 1857-1895.*

Demiralp, I., D’Mello, R., Schlingemann, F., and Subramaniam, V., 2011. Are there monitoring benefits to institutional ownership? Evidence from seasoned equity offerings. Journal of Corporate Finance 17, 1340-1359.*

Deng, X., Hrnjic, E., and Ong, S.E., 2012. Investor sentiment and seasoned equity offerings. SSRN Working Paper no. 2087383, June 7.*

Denis, D.J., 1991. Shelf registration and the market for seasoned equity offerings. Journal of Business 64, 189-212.*

Denis, D.J., 1994. Investment opportunities and the market reaction to equity offerings. Journal of Financial and Quantitative Analysis 29, 159-177.*

DerSimonian, R., and Laird, N., 1986. Meta-analysis in clinical trials. Controlled Clinical Trials 7 , 177-187.

Deshmukh, S., Gamble K.J., and Howe, K.M., 2017. Informed Short Selling around SEO Announcements, Journal of Corporate Finance 46, 121-138.*

Diltz, J.D., Lockwood, L.J., and Min, S., 1992. Sources of wealth loss in new equity issues. Journal of Banking and Finance 16, 511-522.*

Dionysiou, D., 2015. Timing, earnings management and overreaction around pure placings. European Journal of Finance 21, 646-671.*

Dissanaike, G., Faasse, J., and Jayasekera, R., 2014. What do equity issues signal? A study of equity issuances in the UK before and during the financial crisis. Journal of International Money and Finance 49, 358-385.*

D’Mello, R., Tawatnuntachai, O., and Yaman, D., 2003. Why do firms issue equity after splitting stocks? Financial Review 38, 323-350.*

Dong, M., Loncarski, I., ter Horst, J., and Veld, C., 2012. What drives security issuance decisions? Market timing, pecking order, or both. Financial Management 41, 637-663.*

Duca, E., 2016. Do investors learn from the past? Evidence from follow-on equity issues. Journal of Corporate Finance 39, 36-52.* 
Duca, E., Dutordoir, M., Veld, C., and Verwijmeren, P., 2012. Why are convertible bond announcements associated with increasingly negative issuer stock returns? An arbitrage-based explanation. Journal of Banking and Finance 36, 2884-2899.*

Duong, T.X., Singh, R., and Tan, E-J., 2015. What's wrong with rights? Journal of Business Finance and Accounting 42, 1251-1281.*

Dutordoir, M., and Hodrick, L.S., 2012. Self-selection and stock returns around corporate security offering announcements. SSRN Working Paper no. 1764504, January 25.*

Dutordoir, M., Lewis, C., Seward, J., and Veld, C., 2014. What we do and do not know about convertible bond financing. Journal of Corporate Finance 24, 3-20.

Dutordoir, M., Strong, N., and Sun, P., 2017. Corporate social responsibility and seasoned equity offerings. SSRN Working Paper no. 3075198, November 27.*

Eckbo, B.E., 2008. Equity issues and the disappearing rights offer phenomenon. Journal of Applied Corporate Finance 20, 72-85.

Eckbo, B.E., and Masulis, R.W., 1992. Adverse selection and the rights offer paradox. Journal of Financial Economics 32, 293-332.*

Eckbo, B.E., and Masulis, R.W., 1995. Seasoned equity offerings: A survey. In: R. Jarrow, V. Maksimovic, and W. Ziemba (Eds.), Handbooks in Operations Research and Management Science, Vol. 9, Elsevier, 1017-1072.

Eckbo, B.E., Masulis, R.W., and Norli, O., 2007. Security offerings. In: R. Hansen, J. Ritter, and X. $\mathrm{Xu}$ (Eds.), Handbook of Corporate Finance: Empirical Corporate Finance, North-Holland/Elsevier, 233-373.

Elliott, W.B., Prevost, A.K., and Rao, R.P., 2009. The announcement impact of seasoned equity offerings on bondholder wealth. Journal of Banking and Finance 33, 1472-1480.*

Errunza, V.R., and Miller, D., 2003. Valuation effects of seasoned global equity offerings. Journal of Banking and Finance 27, 1611-1623.*

Espenlaub, S., Siougle, G., and Strong, N.C., 2008. Anticipation, asymmetric information and the announcement effect of Greek seasoned equity offerings. SSRN Working Paper no. 1121655.*

Fauver, L., Loureiro, G., and Taboada, A.G., 2017. The impact of regulation on information quality and performance around seasoned equity offerings: International evidence. Journal of Corporate Finance 44, 73-98.*

Ferreira, M., and Laux, P., 2016. Corporate boards and SEOs: The effect of certification and monitoring. Journal of Financial and Quantitative Analysis 51, 899-927.*

Fich, E.M., Starks, L.T., and Yore, A.S., 2014. CEO deal-making activities and compensation. Journal of Financial Economics 114, 471-492.* 
Floros, I.V., and Sapp, T.R.A., 2012. Why do firms issue private equity repeatedly? On the motives and information content of multiple PIPE offerings. Journal of Banking and Finance 36, 3469-3481.*

Fonseka, M.M., Colombage, S.R.N., and Tian, G.-L., 2014. Effects of regulator's announcements, information asymmetry and ownership changes on private equity placements: Evidence from China. Journal of International Financial Markets, Institutions and Money 29, 126-149.*

Francis, B.B., Hasan, I., Lothian, J., and Sun, X., 2010. The signaling hypothesis revisited: Evidence from foreign IPOs. Journal of Financial and Quantitative Analysis 45, 81-106.*

Frank, M.Z., and Goyal, V.K., 2003. Testing the pecking order theory of capital structure. Journal of Financial Economics 67, 217-248.

Furlong, F.T., and Keeley, M.C., 1989. Capital regulation and bank risk-taking: A note. Journal of Banking and Finance 13, 883-891.

Gajewski, J-F., and Ginglinger, E., 2002. Seasoned Equity Issues in a Closely Held Market: Evidence from France. European Finance Review 6, 291-319.*

Gajewski, J-F., Ginglinger, E., and Lasfer, M., 2007. Why do companies include warrants in seasoned equity offerings?. Journal of Corporate Finance 13, 25-42.*

Gao, H., and Mahmudi, H., 2008. Institutional holdings and seasoned equity offerings. SSRN Working Paper no. 1125683, April 29.*

Gao, X., and Ritter, J.R., 2010. The marketing of seasoned equity offerings. Journal of Financial Economics 97, 33-52.*

Ginglinger, E., Matsoukis, L., and Riva, F., 2013. Seasoned equity offerings: Stock market liquidity and the rights offer paradox. Journal of Business Finance and Accounting 40, 215-238.*

Gokkaya, S., and Highfield M.J., 2014. Sales of secondary shares in SEOs: A comparison across top managers, other insiders, and outsiders. Financial Management 43(4), 757 - 794.*

Gokkaya, S., and Roskelley, K.D., 2011. Asymmetric revisions to primary and secondary shares in seasoned equity offerings. SSRN Working Paper no. 1764042, February 15.*

Gokkaya, S., and Roskelley, K.D., 2013. Seasoned equity offerings and ownership structure: A comparison of dual-class and single class SEOs. SSRN Working Paper no. 1766207, August 9.*

Golubov, A., Petmezas, D., and Travlos. N.G., 2016. Do stock-financed acquisitions destroy value? New methods and evidence. Review of Finance, 161-200.*

Graham, J. R., 2000. How big are the tax benefits of debt? Journal of Finance 55, 1901-1941.

Green, B.F., and Hall, J., 1984. Quantitative methods for literature reviews. Annual Review of Psychology 35, 37-54. 
Gropp, R., Mosk, T., Ongena, S., and Wix, C., 2017. Bank response to higher capital requirements: Evidence from a quasi-natural experiment. SSRN Working Paper no. 2877839 , November 11.*

Gustafson, M., 2013. Is quicker cheaper? The consequences of accelerating seasoned equity. SSRN Working Paper no. 1945014, November 12.*

Hadlock, C.J., Ryngaert, M., and Thomas, S., 2001. Corporate structure and equity offerings: Are there benefits to diversification?. Journal of Business 74, 613-635.*

Hansen, R.S., 1988. The demise of the rights issue. Review of Financial Studies 1, 289-309.*

Hansen, R.S., and Crutchley, C., 1990. Corporate earnings and financings: An empirical analysis. Journal of Business 63, 347-371.*

Hansen, R., Ritter, J., and Xu, X., 2007. Handbook of Corporate Finance: Empirical Corporate Finance, North-Holland/Elsevier.

Hao, Q., 2014. Institutional shareholder investment horizons and seasoned equity offerings. Financial Management 43, $87-111$.*

Hauser, S., Kraizberg, E., and Dahan, R., 2003. Price behaviour and insider trading around seasoned equity offerings: The case of majority-owned firms. Journal of Corporate Finance 9, 183-199.*

He, Q., Li, D., Lu, L., and Chong, T.T.L., 2018. Institutional ownership and private equity placements: Evidence from Chinese listed firms. International Review of Finance, forthcoming.*

Heck, J.L., and Cooley, P.L., 2009. Most prolific authors in the finance literature: 1959-2008. SSRN Working Paper no. 1355675, March 8.

Henderson, B.J., and Zhao, B., 2014. More than meets the eye: Convertible bond issuers' concurrent transactions. Journal of Corporate Finance 24, 57-79.*

Heron, R.A., and Lie, E., 2004. A comparison of the motivations for and the information content of different types of equity offerings. Journal of Business 77, 605-632.*

Hertzel, M., Lemmon, M., Linck, J.S., and Rees, L., 2002. Long-run performance following private placements of equity. Journal of Finance 52, 2595-2617.*

Hertzel, M.G., and Li, Z., 2010. Behavioral and rational explanations of stock price performance around SEOs: Evidence from a decomposition of market-to-book ratios. Journal of Financial and Quantitative Analysis 45, 935-958.

Hertzel, M., and Smith, R., 1993. Market discounts and shareholder gains for placing equity privately. Journal of Finance 48, 459-485.*

Higgins, E.J., Howton, S., and Howton, S., 2002. Information transfers across same-sector funds when closed-end funds issue equity. Financial Review 37, 551-561.* 
Higgins, E.J., Howton, S., and Howton, S., 2003. An analysis of closed-end fund seasoned equity offerings. Journal of Financial Research 26, 243-257.*

Holderness, C.G., 2018. Equity issuances and agency costs: The telling story of shareholder approval around the world. Journal of Financial Economics (forthcoming).*

Holderness, C.G., and Pontiff, J., 2016. Shareholder nonparticipation in valuable rights offerings: New findings for an old puzzle. Journal of Financial Economics 120, 252-268.*

Hovakimian, A., and Hutton, I., 2010. Market feedback and equity issuance: Evidence from repeat equity issues. Journal of Financial and Quantitative Analysis 45, 739-762.*

Huang, Y., Uchida, K., and Zha, D., 2016. Market timing of seasoned equity offerings with long regulative process. Journal of Corporate Finance 39, 278-294.*

Huang, Y., Uchida, K., and Zha, D., 2017. Market timing in private placements of equity. SSRN Working Paper no. 2904861 , August 18.*

Huang, Z., Zhao, L., and Mao, X., 2009. Is the demand curve for stocks downward-sloping? New evidence from seasoned equity offerings. SSRN Working Paper no. 1361610, March 17.*

Intintoli, V.J., and Kahle, K.M., 2010. Seasoned equity offers: The effect of insider ownership and float. Financial Management 39, 1575-1599.*

Iqbal, A., 2008. The importance of the sequence in UK rights issues. Journal of Business Finance and Accounting 35, 150-176.*

Jain, P.C., 1992. Equity issues and changes in expectations of earnings by financial analysts. Review of Financial Studies 5, 669-683.*

Jegadeesh, N., Weinstein, M., and Welch, I., 1993. An empirical investigation of IPO returns and subsequent equity offerings. Journal of Financial Economics 34, 153-175.*

Jensen, M.C., 1986. Agency costs of free cash flow, corporate finance, and takeovers. American Economic Review 76, 323-329.

Jiang, Y., Stohs, M.H., and Xie, X., 2013. Do firms time seasoned equity offerings? Evidence from SEOs issued shortly after IPOs. SSRN Working Paper no. 1117281, October 1.*

Johnson, W.C., Kang, J-K., Masulis, R.W., and Yi, S., 2018. Seasoned equity offerings and customersupplier relationships. Journal of Financial Intermediation 33, 98-114.*

Kabir, R., and Roosenboom, P., 2003. Can the stock market anticipate future operating performance? Evidence from equity rights issues. Journal of Corporate Finance 9, 93-113.*

Kadiyala, P. and Rau P.R., 2004. Investor reaction to corporate event announcements: Underreaction or overreaction. Journal of Business 77, 357-386.* 
Kalay, A., and Shimrat, A., 1987. Firm value and seasoned equity issues: Price pressure, wealth redistribution, or negative information. Journal of Financial Economics 19, 109-126.*

Kang, J.-K., and Stulz, R.M., 1996. How different is Japanese corporate finance? An investigation of the information content of new security issues. Review of Financial Studies 9, 109-139.*

Karolyi, G.A., 2016. Home bias, an academic puzzle. Review of Finance 20, 2049-2078.

Karpavicius, S., and Suchard, J-A., 2010. Shelf registrations and offerings: intra-industry effects. SSRN Working Paper no. 1297622, June 11.*

Kato, K., and Schallheim, J.S., 1993. Private equity financings in Japan and corporate grouping (Keiretsu). Pacific-Basin Finance Journal 1, 287-307.*

Kato, H.K., and Suzuki, K., 2012. Does divergence of opinion affect stock returns? Evidence from Japanese SEOs. SSRN Working Paper no. 2023490, November 10.*

Kennedy, D.B., Sivakumar, R., and Vetzal, K.R., 2006. The implications of IPO underpricing for the firm and insiders: Tests of asymmetric information theories. Journal of Empirical Finance 13, 49-78.*

Kim, E.H., and Purnanandam, A., 2014. Seasoned equity offerings, corporate governance, and investments. Review of Finance 18, 1023-1057.*

Koenig-Matsoukis, L., 2012. Informed trading around rights issues. SSRN Working Paper no. 1868224, December 16.*

Korajczyk, R.A., Lucas, D.J., and McDonald, R.J., 1991. The effect of information releases on the pricing and timing of equity issues. Review of Financial Studies 4, 685-708.*

Korteweg, A.G., and Renneboog, L., 2003. The choice between rights-preserving issue methods, regulatory and financial aspects of issuing seasoned equity in the UK. SSRN Working Paper no. 389001, March.*

Krakstad, S.O., and Molnar, P., 2015. Characteristics of Norwegian Rights Issues. SSRN Working Paper no. 2691517, November 18.*

Krishnamurthy, S., Spindt, P., Subramaniam, V., and Woidtke, T., 2005. Does investor identity matter in equity issues? Evidence from private placements. Journal of Financial Intermediation 14, 210-238.*

Krishnan, C.N.V., Ergungor, O.E., Laux, P.A., Singh, A.K., and Zebedee, A.A., 2010. Examining bank SEOs: Are offers made by undercapitalized banks different? Journal of Financial Intermediation 19, 207-234.*

Kysucky, V., and Norden, L., 2016. The benefits of relationship lending in a cross-country context: A meta-analysis. Management Science 62, 90-110.

La Porta, R., Lopez-de-Silanes, F., Shleifer, A. and Vishny, R.W., 1997. Legal determinants of external finance. Journal of Finance 52, 1131-1150. 
Lease, R.C., Masulis, R.W., and Page, J.R., 1991. An investigation of market microstructure impacts on event study returns. Journal of Finance 46, 1523-1536.*

Lee, I., 1997. Do firms knowingly sell overvalued equity?, 1997. Journal of Finance 52, 1439-1466.*

Lee, G., and Masulis, R.W., 2009. Seasoned equity offerings: Quality of accounting information and expected flotation costs. Journal of Financial Economics 92, 443-469.*

Lee, C.C., Poon W.C., and Sinnakkannu, J., 2014. Why are rights offers in Hong Kong so different? Pacific-Basin Finance Journal 26, 176-197.*

Lee, C.C., Poon W.C., and Sinnakkannu, J., 2017. Selection bias and the underwriter certification of the largest shareholders in seasoned equity offerings. International Review of Finance, 1-35.*

Li, H., Liu, H., and Siganos, A., 2016. A comparison of the stock market reactions of convertible bond offerings between financial and non-financial institutions: Do they differ? International Review of Financial Analysis 45, 356-366.

Li, H., Liu, H., and Veld, C., 2017. The effects of bank regulation stringency on seasoned equity offering announcements. SSRN Working Paper no. 2925800, March 5.*

Liang, H-C., and Jang, W-Y., 2013. Information asymmetry and monitoring in equity private placements. Quarterly Review of Economics and Finance 53, 460-475.*

Lim, J., Schwert, M.W., and Weisbach, M.S., 2017. The economics of PIPEs. SSRN Working Paper no. 3056286 , February 18.*

Lin, Y-M., You, S-J., and Lin, F-J., 2008. The effects of pre-issue information releases on seasoned equity offerings. Journal of Business Finance and Accounting 35, 1138-1163.*

Liu, J., Akbar, S., Shah, S.Z.A., Zhang, D., and Pang, D., 2016. Market reaction to seasoned offerings in China, Journal of Business Finance and Accounting 43, 597-653.*

Loderer, C., Cooney, J.W., and van Drunen, L.D., 1991. The price elasticity of demand for common stock. Journal of Finance 46, 621-651.*

Loderer, C.F., and Mauer, D. C., 1992. Corporate dividends and seasoned equity issues: An empirical investigation. Journal of Finance 47, 201-225.

Manuel, T.A., Brooks, L.D., and Schadler, F.P., 1993. Common stock price effects of security issues conditioned by current earnings and dividend announcements. Journal of Business 66, 571-593.*

Marciukaityte, D., and Pennathur, A.K., 2007. Equity with warrants in private placements. Financial Review 42, 143-160.*

Marisetty, V.B., Marsden, A., and Veeraraghavan, M., 2008. Price reaction to rights issues in the Indian capital market. Pacific-Basin Finance Journal 16, 316-340.* 
Marsden, A., 2000. Shareholder wealth effects of rights issues: Evidence from the New Zealand capital market. Pacific-Basin Finance Journal 8, 419-442.*

Martin-Ugedo, J.F., 2003. Equity rights issues in Spain: Flotation costs and wealth effects. Journal of Business Finance \& Accounting 30, 1277-1304.*

Massa, M., Mataigne, V., Vermaelen, T., and Xu, M., 2016. Choices in equity finance: A global perspective. SSRN Working Paper no. 2755943 , April 2.*

Massa, M., Vermaelen, T., and Xu, M., 2013. Rights offerings, trading, and regulation: A global perspective. SSRN Working Paper no. 2340504, December 13.*

Masulis, R.W., and Korwar, A.N., 1986. Seasoned equity offerings: An empirical investigation, Journal of Financial Economics 15, 91-118.*

Mayers, D., 1998. Why firms issue convertible bonds: The matching of financial and real investment options. Journal of Financial Economics 47, 83-102.

Maynes, E., and Pandes, J.A., 2011. The wealth effects of reducing private placement resale restrictions. European Financial Management 17, 500-531.*

Michaely, R., Rubin, A., and Vedrashko, A., 2016. Are Friday announcements special? Overcoming selection bias. Journal of Financial Economics 122, 65-85.*

Mikkelson, W.H., and Partch, M.M., 1986. Valuation effects of security offerings and the issuance process. Journal of Financial Economics 15, 31-60.*

Moerland, P.W., 1995. Alternative disciplinary mechanisms in different corporate systems. Journal of Economic Behavior and Organization 26, 17-34.

Moore, N.H., Peterson, D.R., and Peterson, P.P., 1986. Shelf registrations and shareholder wealth: A comparison of shelf and traditional equity offerings. Journal of Finance 51, 451-463.*

Morita, H., 2016. Another Welfare Effect of Insider Trading? An Empirical Analysis of Insider Trading around Seasoned Equity Offering in Japan. SSRN Working Paper no. 2790713, June 14.*

Myers, S.C., 1984. The capital structure puzzle. Journal of Finance 39, 575-592.

Myers, S.C., and Majluf, N., 1984. Corporate financing and investment decisions when firms have information that investors do not have. Journal of Financial Economics 13, 187-221.

Nelson, J.P., and Kennedy, P.E., 2009. The use (and abuse) of meta-analysis in environmental and natural resource economics: an assessment. Environmental and Resource Economics 42, 345-377.

Pandes, J.A., 2010. Bought deals: The value of underwriter certification in seasoned equity offerings. Journal of Banking and Finance 34, 1576-1589.*

Park, J.L., 2014. Equity issuance, distress, and agency problems: the $20 \%$ rule for privately issued equity, SSRN working paper no. 2139507, March 12.* 
Petersen, M. A., 2009. Estimating standard errors in finance panel data sets: Comparing approaches. Review of Financial Studies 22, 435-480.

Pettway, R.H., and Radcliffe, R.C., 1985. Impacts of new equity sales upon electric utility share prices. Financial Management 14, 16-25.*

Pilotte, E., 1992. Growth opportunities and the stock price response to new financing. Journal of Business 65, 371-394.*

Pinto-Gutierrez, C., 2015. The effect of investor attention on the pricing of seasoned equity offerings, SSRN Working Paper, August.*

Poloncheck, J., Slovin, M.B., and Sushka, M.E., 1989. Valuation effects of commercial bank securities offerings: A test of the information hypothesis. Journal of Banking and Finance 13, 443-461.*

Prakash, P., Rangan, N., and Salandro, D., 2011. Why did non-dividend paying firms benefit more from the 2003 dividend tax cut? Evidence from SEOs. SSRN Working Paper no. 1972527, December 12.*

Qian, H., Zhong, K., and Zhong, Z., 2012. Seasoned equity issuers' R\&D investments: Signaling or overoptimism. Journal of Financial Research 35, 553-580.*

Rauterkus, S.Y., and Song, K.R., 2005. Auditor's reputation and equity offerings: The case of Arthur Andersen. Financial Management 34 (Winter), 121-135.*

Rogers, W.H., 1993. Regression standard errors in clustered samples. Stata Technical Bulletin 13, 1923.

Salamudin, N., Ariff, M., and Nassir, A.M., 1999. Economic influence on rights issue announcement behaviour in Malaysia. Pacific-Basin Finance Journal 7, 405-427.*

Sant, R., and Ferris, S.P., 1994. Seasoned equity offerings: The case of all-equity firms. Journal of Business Finance \& Accounting 21, 429-444.*

Schipper, K., and Smith, A., 1986. A comparison of equity carve-outs and seasoned equity offerings: Share price effects and corporate restructuring. Journal of Financial Economics 15, 153-86.*

Schultz, P., 1993. Calls of warrants: Timing and market reaction. Journal of Finance 48, 681-696.

Shimizu, K., and Xu, P., 2014. The costs of bank equity offerings in response to strengthened capital regulation, SSRN Working Paper no. 2427535, April 21.*

Silva, A., and Bilinski, P., 2015, Intended use of proceeds, underwriter quality and the long-run performance of SEOs in the UK. Journal of Business Finance and Accounting 42, 1282-1309.*

Singh, A.K., 1997. Layoffs and underwritten rights offers. Journal of Financial Economics 43, $105-$ $130{ }^{*}$

Slovin, M.B., and Sushka, M.E., 1997. The implication of equity issuance decisions within a parentsubsidiary governance structure. Journal of Finance 52, 841-857.* 
Slovin, M.B., Sushka, M.E., and Bendeck, Y.M., 1994. Seasoned common stock issuance following an IPO. Journal of Banking and Finance 18, 207-226.*

Slovin, M.B., Sushka, M.E., and Lai, K.W.L., 2000. Alternative flotation methods, adverse selection and ownership structure: Evidence from seasoned equity issuance in the U.K. Journal of Financial Economics 57, 157-190.*

Smart, S., Zutter, C.J., and Megginson, W.L., 2008. The evolution of equity financing: A comparison of dual-class and single-class SEOs. SSRN Working Paper no. 1081765, January 8.*

Smith, C.W., 1977. Alternative methods for raising capital: Rights versus underwritten offerings. Journal of Financial Economics 5, 273-307.

Smith, C., 1986. Investment banking and the capital acquisition process. Journal of Financial Economics 15, 3-30.

Song, Q., 2009. Returns post catastrophe induced seasoned equity offerings of property and casualty insurance companies. SSRN Working Paper no. 1138026, March 25.*

Tandon, K., Yu, S., and Webb, G., 2010. Option introduction and secondary equity offerings. Journal of Applied Finance 1, 47-63.*

Tripathy, N., and Rao, R.P., 1992. Adverse selection, spread behaviour, and over-the-counter seasoned equity offerings. Journal of Financial Research 15, 39-56.*

Tsangarakis, N.V., 1996. Shareholder wealth effects of equity issues in emerging markets: Evidence from rights offerings in Greece. Financial Management 25, 21-32.*

Twu, M., 2010. Does the order between dividend payment and new stock issuance matter to stock price? Evidence from Taiwan. Review of Pacific Basin Financial Markets and Policies 13, 363-380.*

Varma, R., and Szewczyk, S.H., 1993. The private placement of bank equity. Journal of Banking and Finance 17, 1111-1131.*

Veld, C., and Veld-Merkoulova, Y., 2009. Value creation through spin-offs: A review of empirical evidence. International Journal of Management Reviews 11, 407-420.

Vijh, A., 2006. Does a parent-subsidiary structure enhance financing flexibility? Journal of Finance $61,1337-1360$ * $^{*}$

Walker, M.D., and Wu, Q., 2017. Equity issues when in distress. SSRN Working Paper no. 2955760, June 3.*

Walker, M.D., and Yost, K., 2008. Seasoned equity offerings: what firms say, do, and how the market reacts. Journal of Corporate Finance 14, 376-386.*

Walker, M.D., Yost, K., and Zhao, J., 2016. Credibility and multiple SEOs: What happens when firms return to the capital market? Financial Management 45, 675-703.* 
Wang, Y., Chen, S.-S., and Cheng, Y.-T., 2011. Revisiting corporate dividends and seasoned equity offerings. Review of Quantitative Finance and Accounting 36, 133-151.*

Wang, K., Chen, Y.-H., and Huang, S.-Z., 2008. Agency theory and flotation methods in seasoned equity offerings: The case in Taiwan. Review of Pacific Basin Financial Markets and Policies 11, 555567.*

Wansley, J.W., and Dhillon, U.S., 1989. Determinants of valuation effects for security offerings of commercial bank holding companies. Journal of Financial Research 12, 217-234.*

Wruck, K.H., 1989. Equity ownership concentration and firm value: Evidence from private equity financings. Journal of Financial Economics 23, 3-28.*

Wruck, K.H., and Wu, Y., 2009. Relationships, corporate governance, and performance: Evidence from private placements of common stock. Journal of Corporate Finance 15, 30-47.*

Wu, C., and Kwok, C.C.Y., 2002. Why do US firms choose global equity offerings? Financial Management 31, 47-65.*

Wu, X. and Wang, Z., 2002. Why Do Firms Choose Value-Destroying Rights Offerings? Theory and Evidence from Hong Kong. SSRN Working Paper no. 302618, March 21.*

Wu, X., Wang, Z., and Yao, J., 2005. Understanding the positive announcement effects of private equity placements: New insights from Hong Kong data. Review of Finance 9, 385-414.*

Yeh, Y.H., Shu, P.G., and Kao, M.S., 2015. Corporate governance and private equity placements. Review of Pacific Basin Financial Markets and Policies 18, 1-31.*

Zeidler, F., Mietzner, M., and Schiereck, D., 2012. Risk dynamics surrounding the issuance of convertible bonds. Journal of Corporate Finance 18, 273-290.*

Zhang, S., 2005. Underpricing, share overhang, and insider selling in follow-on offerings. Financial Review 40, 409-428.*

Zhang, W., 2013. The impact of cost of equity on seasoned equity offerings. SSRN Working Paper no. 2320552, September 4.*. 
Table 1: Sources of the papers included in the meta-analysis

\begin{tabular}{|c|c|}
\hline Source & Number of papers \\
\hline \multicolumn{2}{|l|}{ List of 26 journals from Heck and Cooley (2009) } \\
\hline Financial Analysts Journal (FAJ) & 0 \\
\hline Financial Management (FM) & 10 \\
\hline Financial Review (FR) & 5 \\
\hline Journal of Applied Corporate Finance (JACF) & 0 \\
\hline Journal of Applied Finance/Financial Practice and Education (JAF) & 1 \\
\hline Journal of Banking and Finance (JBF) & 12 \\
\hline Journal of Business Finance and Accounting (JBFA) & 9 \\
\hline Journal of Corporate Finance (JCF) & 21 \\
\hline Journal of Derivatives (JD) & 0 \\
\hline Journal of Empirical Finance (JEF) & 2 \\
\hline Journal of Finance (JF) & 10 \\
\hline Journal of Financial and Quantitative Analysis (JFQA) & 6 \\
\hline Journal of Financial Economics (JFE) & 22 \\
\hline Journal of Financial Intermediation (JFI) & 5 \\
\hline Journal of Financial Markets (JFM) & 0 \\
\hline Journal of Financial Research (JFR) & 8 \\
\hline Journal of Financial Services Research (JFSR) & 0 \\
\hline Journal of Futures Markets (JFutM) & 0 \\
\hline Journal of Money, Credit and Banking (JMCB) & 0 \\
\hline Journal of Portfolio Management (JPM) & 0 \\
\hline Pacific Basin Finance Journal (PBFJ) & 8 \\
\hline Quarterly Review of Economics and Finance (QREF) & 1 \\
\hline Review of Derivatives Research (RDR) & 0 \\
\hline Review of Financial Studies (RFS) & 5 \\
\hline Review of Pacific Basin Financial Markets and Policies (RPBFMP) & 4 \\
\hline Review of Quantitative Finance and Accounting (RQFA) & 1 \\
\hline Additional journals & 0 \\
\hline Accounting and Finance (AF) & 1 \\
\hline Critical Finance Review (CFR) & 0 \\
\hline European Financial Management (EFM) & 4 \\
\hline International Review of Finance (IRF) & 2 \\
\hline International Review of Financial Analysis (IRFA) & 1 \\
\hline Journal of International Financial Markets, Institutions and Money (JIFMIM) & 2 \\
\hline Journal of International Money and Finance (JIMF) & 1 \\
\hline European Journal of Finance (EJF) & 4 \\
\hline Journal of Business (JB) & 10 \\
\hline Review of Asset Pricing Studies (RAPS) & 0 \\
\hline Review of Corporate Finance Studies (RCFS) & 1 \\
\hline Review of Finance (European Finance Review) (RF/EFR) & 5 \\
\hline \multicolumn{2}{|l|}{ Working papers } \\
\hline Social Science Research Network (SSRN) & 37 \\
\hline TOTAL & 198 \\
\hline
\end{tabular}


Table 2: Studies of the market reaction to announcements of seasoned equity offerings

\begin{tabular}{|c|c|c|c|c|c|c|c|}
\hline Study & Journal & Country & $\begin{array}{l}\text { Research } \\
\text { period }\end{array}$ & $\begin{array}{l}\text { Event } \\
\text { window }\end{array}$ & $\begin{array}{l}\text { Number } \\
\text { of obs }\end{array}$ & CAR & Significance \\
\hline \multicolumn{8}{|l|}{ Market-oriented country studies } \\
\hline Bhagat, Marr, and Thompson (1985) & $\mathrm{JF}$ & US & $1982-1983$ & $(0,1)$ & 344 & -1.43 & $\begin{array}{l}\text { Calculated as the } \\
\text { samples of respect } \\
1.17 \% \text { ) and } 251 \text { ol }\end{array}$ \\
\hline Pettway and Radcliffe (1985) & FM & US & $1973-1980$ & $(-1,0)$ & 366 & -0.51 & $* * *$ \\
\hline Asquith and Mullins (1986) & JFE & US & $1963-1981$ & $(-1,0)$ & 266 & -2.7 & $* * *$ \\
\hline Masulis and Korwar (1986) & JFE & US & $1963-1980$ & $(0,1)$ & 972 & -1.71 & $\begin{array}{l}\text { Calculated as the } \\
\text { samples of respect } \\
-3.25 \% \text { ) and } 584\end{array}$ \\
\hline Mikkelson and Partch (1986) & JFE & US & 1972-1982 & $(-1,0)$ & 56 & -3.44 & $* * *$ \\
\hline Moore, Peterson, and Peterson (1986) & $\mathrm{JF}$ & US & $1982-1983$ & $(-1,1)$ & 229 & -1.82 & $\begin{array}{l}\text { Calculated as the } \\
\text { samples of respect } \\
0.8 \% \text { ), } 53 \text { observa } \\
\text { observations (CAI } \\
\text { observations (CAI }\end{array}$ \\
\hline Schipper and Smith (1986) & JFE & US & $1965-1983$ & $(-4,0)$ & 39 & -0.35 & $* * *$ \\
\hline Kalay and Shimrat (1987) & JFE & US & 1970-1982 & $(0,0)$ & 455 & -3.78 & $* * *$ \\
\hline Barclay and Litzenberger (1988) & JFE & US & $1981-1983$ & $(0,1)$ & 218 & 0.48 & $* * *$ \\
\hline Hansen (1988) & RFS & US & $1964-1986$ & $(-1,0)$ & 102 & -2.99 & $\begin{array}{l}\text { Calculated as the } \\
\text { samples of respect } \\
1.21 \% \text { ) and } 22 \mathrm{ob}\end{array}$ \\
\hline Poloncheck, Slovin, and Sushka (1989) & JBF & US & $1975-1984$ & $(-1,1)$ & 44 & -1.38 & $* * *$ \\
\hline Wansley and Dhillon (1989) & JFR & US & $1978-1985$ & $(0,1)$ & 19 & 1.51 & $* * *$ \\
\hline Wruck (1989) & JFE & US & $1979-1985$ & $(-1,0)$ & 99 & 1.89 & $*$ \\
\hline Hansen and Crutchley (1990) & JB & US & $1975-1982$ & $(-1,0)$ & 109 & -3.65 & $* * *$ \\
\hline Bayless and Chaplinsky (1991) & JFI & US & 1974-1983 & $(-1,0)$ & 223 & -0.03 & $* * *$ \\
\hline Denis (1991) & JB & US & $1982-1986$ & $(-1,0)$ & 83 & -1.06 & $\begin{array}{l}\text { Calculated as the } \\
\text { samples of respect } \\
4.33 \% \text { ), } 8 \text { observa } \\
\text { observations (CAI } \\
\text { observations (CAI }\end{array}$ \\
\hline Korajczyk, Lucas, and McDonald (1991) & RFS & US & $1978-1983$ & $(-1,0)$ & 1024 & -2.69 & $* * *$ \\
\hline Lease, Masulis, and Page (1991) & $\mathrm{JF}$ & US & 1981-1983 & $(-1,0)$ & 405 & -0.12 & n.r. \\
\hline Loderer, Cooney, and van Drunen (1991) & $\mathrm{JF}$ & US & 1969-1982 & $(-1,0)$ & 430 & -0.93 & ** \\
\hline Brous and Kini (1992) & JFR & US & $1986-1985$ & $(-1,1)$ & 246 & -2.64 & $* * *$ \\
\hline Diltz, Lockwood, and Min (1992) & JBF & US & $1980-1988$ & $(-1,0)$ & 234 & -2.4 & n.r. \\
\hline Eckbo and Masulis (1992) & JFE & US & $1963-1981$ & $(-1,0)$ & 1216 & -1.52 & $\begin{array}{l}\text { Calculated as the } \\
\text { samples of respect } \\
-3.34 \%), 646 \text { obse } \\
\text { observations (CAI } \\
(\text { CAR }=-0.53 \%) \\
1.39 \%) \text {, and } 27 \mathrm{ob}\end{array}$ \\
\hline Jain (1992) & RFS & US & $1979-1983$ & $(-2,0)$ & 269 & -2.89 & $* * *$ \\
\hline Pilotte (1992) & JB & US & $1963-1984$ & $(-1,0)$ & 279 & -3.85 & n.r. \\
\hline Tripathy and Rao (1992) & JFR & US & 1980-1984 & $(-1,0)$ & 138 & -2.62 & $* * *$ \\
\hline Choe, Masulis, and Nanda (1993) & JEF & US & $1963-1983$ & $(-1,0)$ & 1456 & -1.39 & $\begin{array}{l}\text { Calculated as the } \\
\text { samples of respect } \\
-2.42 \% \text { ) and } 787\end{array}$ \\
\hline Hertzel and Smith (1993) & $\mathrm{JF}$ & US & $1980-1987$ & $(-3,0)$ & 106 & 1.72 & $* * *$ \\
\hline Jegadeesh, Weinstein, and Welch (1993) & JFE & US & 1980-1986 & $(-1,1)$ & 411 & -1.16 & n.s. \\
\hline
\end{tabular}




\begin{tabular}{|c|c|c|c|c|c|c|c|}
\hline Manuel, Brooks, and Schadler (1993) & JB & US & $1971-1986$ & $(-1,0)$ & 191 & -2.84 & $* * *$ \\
\hline Varma and Szewczyk (1993) & JBF & US & $1975-1988$ & $(-1,0)$ & 62 & -0.98 & n.r. \\
\hline Denis (1994) & JFQA & US & $1977-1990$ & $(0,1)$ & 435 & -2.49 & $* * *$ \\
\hline Sant and Ferris (1994) & JBFA & US & $1965-1987$ & $(-1,0)$ & 61 & -1.44 & $* * *$ \\
\hline Bayless and Chaplinsky (1996) & $\mathrm{JF}$ & US & $1968-1990$ & $(-1,0)$ & 1884 & -2.32 & $\begin{array}{l}\text { Calculated as the } \\
\text { samples of respect } \\
=-2 \% \text { ), } 288 \text { obser } \\
\text { observations (CAI }\end{array}$ \\
\hline Lee (1997) & $\mathrm{JF}$ & US & 1980-1984 & $(-1,0)$ & 405 & -2.91 & $* * *$ \\
\hline Singh (1997) & JFE & US & $1963-1985$ & $(-1,0)$ & 63 & -1.07 & $* * *$ \\
\hline Slovin and Sushka (1997) & $\mathrm{JF}$ & US & $1975-1993$ & $(-1,0)$ & 38 & -4.06 & $* * *$ \\
\hline Slovin, Sushka, and Bendeck (1994) & JBF & US & $1973-1988$ & $(-1,0)$ & 175 & -2.87 & $* * *$ \\
\hline Akhigbe and Madura (2001) & FR & US & 1983-1996 & $(-1,1)$ & 105 & -0.63 & $* * *$ \\
\hline Clarke, Dunbar, and Kahle (2001) & JFQA & US & 1984-1996 & $(-1,1)$ & 3266 & -1.79 & $\begin{array}{l}\text { Calculated as the } \\
\text { samples of respect } \\
-3.3 \% \text { ) and } 3092 \\
\end{array}$ \\
\hline Hadlock, Ryngaert, and Thomas (2001) & JB & US & 1983-1994 & $(0,1)$ & 641 & -2.62 & n.r. \\
\hline Hertzel, Lemmon, Linck, and Rees (2002) & $\mathrm{JF}$ & US & 1980-1996 & $(-3,0)$ & 619 & 2.4 & $* * *$ \\
\hline Wu and Kwok (2002) & FM & US & 1985-1995 & $(-1,0)$ & 2069 & -1.86 & n.r. \\
\hline Altınk1lıc and Hansen (2003) & JFE & US & $1990-1997$ & $(0,0)$ & 1703 & 1.7 & $* * *$ \\
\hline Byoun and Moore (2003) & $\mathrm{JCF}$ & US & $1980-1997$ & $(-1,0)$ & 4259 & -2.64 & n.r. \\
\hline D'Mello, Tawatnuntachai, and Yaman (2003) & FR & US & 1980-1995 & $(-1,1)$ & 2190 & -1.63 & n.r. \\
\hline Higgins, Howton, and Howton (2003) & JFR & US & 1980-1997 & $(0,0)$ & 99 & -0.65 & $* *$ \\
\hline Byoun (2004) & JB & US & $1980-1997$ & $(-1,0)$ & 4259 & -2.64 & n.r. \\
\hline Chang and Shin (2004) & PBFJ & US & $1997-2000$ & $(-1,1)$ & 673 & -2.27 & $* * *$ \\
\hline Clarke, Dunbar, and Kahle (2004) & JB & US & $1980-1996$ & $(-1,1)$ & 424 & -2.25 & $* * *$ \\
\hline Heron and Lie (2004) & JB & US & 1980-1998 & $(-1,1)$ & 4708 & -2.32 & n.r. \\
\hline Kadiyala and Rau (2004) & JB & US & 1980-1994 & $(-1,1)$ & 720 & -2.56 & $* * *$ \\
\hline Datta, Iskandar-Datta, and Raman (2005) & JB & US & 1992-1999 & $(-1,1)$ & 444 & -1.7 & $* * *$ \\
\hline Krishnamurthy, Spindt, Subramaniam, and Woidtke (2005) & JFI & US & 1983-1992 & $(-1,0)$ & 397 & 1.43 & $* * *$ \\
\hline Rauterkus and Song (2005) & FM & US & 2001-2002 & $(0,1)$ & 163 & -2.55 & n.r. \\
\hline Zhang (2005) & FR & US & $1990-2000$ & $(-1,1)$ & 3857 & -1.76 & $\begin{array}{l}\text { Calculated as the } \\
\text { samples of respect } \\
-2.4 \% \text { ) and } 2939\end{array}$ \\
\hline Akhigbe, Newman, and Safieddine (2006) & JFR & US & $1987-2001$ & $(-1,1)$ & 2360 & -2.21 & $\begin{array}{l}\text { Calculated as the } \\
\text { samples of respect } \\
=-2.78 \% \text { ) and } 260\end{array}$ \\
\hline Brooks, Chen, and Yu (2006) & SSRN & US & $1980-2002$ & $(-1,1)$ & 5975 & -2.1 & $* * *$ \\
\hline Kennedy, Sivakumar, and Vetzal (2006) & JEF & US & $1991-2000$ & $(-1,0)$ & 514 & -1.68 & $* * *$ \\
\hline Vijh (2006) & $\mathrm{JF}$ & US & 1981-2002 & $(-1,1)$ & 90 & -0.11 & n.s. \\
\hline Barclay, Holderness, and Sheehan (2007) & $\mathrm{JCF}$ & US & 1979-1997 & $(-1,0)$ & 559 & 1.7 & $* * *$ \\
\hline Dai (2007) & $\mathrm{JCF}$ & US & $1995-2003$ & $(0,3)$ & 510 & 0.31 & n.r. \\
\hline Marciukaityte and Pennathur (2007) & FR & US & 1981-1996 & $(-3,0)$ & 671 & 3.69 & $\begin{array}{l}\text { Calculated as the } \\
\text { samples of respect } \\
3.93 \% \text { ) and } 172 \text { ol }\end{array}$ \\
\hline Aggarwal and Zhao (2008) & IRFA & US & $1983-2003$ & $(-1,1)$ & 2166 & -2.59 & $* * *$ \\
\hline
\end{tabular}




\begin{tabular}{|c|c|c|c|c|c|c|c|}
\hline Autore, Kumar, Shome (2008) & JCF & US & $1990-2003$ & $(-1,1)$ & 1198 & -1.25 & $\begin{array}{l}\text { Calculated as the } \\
\text { samples of respect } \\
-1.61 \% \text { ) and } 341 \\
\end{array}$ \\
\hline Gao and Mahmudi (2008) & SSRN & US & $1980-2004$ & $(-1,1)$ & 6950 & -1.6 & n.s. \\
\hline Smart, Megginson, and Zutter (2008) & SSRN & US & $1990-2001$ & $(-1,1)$ & 1962 & -2.09 & n.r. \\
\hline Walker and Yost (2008) & $\mathrm{JCF}$ & US & $1997-2000$ & $(0,1)$ & 438 & -2.76 & n.r. \\
\hline Elliott, Prevost, and Rao (2009) & $\mathrm{JBF}$ & US & $1990-2002$ & $(-1,0)$ & 99 & -1.1 & $* * *$ \\
\hline Lee and Masulis (2009) & JFE & US & 1990-2002 & $(0,1)$ & 963 & -2.67 & $* * *$ \\
\hline Song (2009) & SSRN & US & $1981-2006$ & $(-1,0)$ & 111 & -0.42 & n.s. \\
\hline Wruck and Wu (2009) & $\mathrm{JCF}$ & US & 1980-1999 & $(-3,0)$ & 1818 & 2.02 & $* * *$ \\
\hline Adler and Shea (2010) & SSRN & US & $1982-2007$ & $(0,1)$ & 717 & -0.44 & $*$ \\
\hline Chemmanur, Michel, Nandy, and Yan (2010) & SSRN & US & 1980-2004 & $(0,1)$ & 5630 & -0.8 & $* * *$ \\
\hline Chen, Cheng, Cheng, and Chih (2010) & $\mathrm{JBF}$ & US & $1997-2003$ & $(-1,0)$ & 288 & 2.48 & $* * *$ \\
\hline Chen, Dai, and Schatzberg (2010) & $\mathrm{JCF}$ & US & $1996-2006$ & $(-4,5)$ & 3821 & 3.34 & n.r. \\
\hline Francis, Hasan, Lothian, and Sun (2010) & JFQA & US & $1985-2000$ & $(-1,1)$ & 70 & -0.02 & n.s. \\
\hline Gao and Ritter (2010) & JFE & US & 1996-2007 & $(-1,0)$ & 3276 & -1.72 & n.r. \\
\hline Hovakimian and Hutton (2010) & JFQA & US & $1970-2003$ & $(-1,1)$ & 3404 & 0.2 & $\begin{array}{l}\text { Calculated as the } \\
\text { samples of respect } \\
=0.16 \% \text { ) and } 196\end{array}$ \\
\hline Intintoli and Kahle (2010) & FM & US & $1980-2004$ & $(-5,0)$ & 7720 & -2.04 & $\begin{array}{l}\text { Calculated as the } \\
\text { samples of respect } \\
=5.01 \% \text { ) and } 480\end{array}$ \\
\hline Karpavičius and Suchard (2010) & SSRN & US & $1996-2005$ & $(-1,0)$ & 165 & -2.09 & $* * *$ \\
\hline Krishnan, Ergungor, Laux, Singh, and Zebedee (2010) & JFI & US & $1983-2005$ & $(-1,0)$ & 276 & -0.85 & $\begin{array}{l}\text { Calculated as the } \\
\text { samples of respect } \\
0.81 \% \text { ) and } 203 \text { of }\end{array}$ \\
\hline Tandon, Yu, and Webb (2010) & JAF & US & $1980-2005$ & $(-1,0)$ & 2526 & -1.44 & n.r. \\
\hline Ang and Cheng (2011) & JFR & US & $1980-1995$ & $(-3,3)$ & 202 & -1.2 & $* * *$ \\
\hline Autore, Hutton and Kovacs (2011) & EFM & US & $1997-2005$ & $(0,1)$ & 628 & -2.07 & n.r. \\
\hline Booth and Chang (2011) & JFR & US & $1975-2002$ & $(-1,0)$ & 1731 & -2.59 & $\begin{array}{l}\text { Calculated as the } \\
\text { samples of respect } \\
2.8 \% \text { ) and } 1183 \text { ol }\end{array}$ \\
\hline Demiralp, D’Mello, Schlingemann, and Subramaniam (2011) & $\mathrm{JCF}$ & US & $1982-2006$ & $(-1,1)$ & 3093 & -1.39 & $* * *$ \\
\hline Gokkaya and Roskelley (2011) & SSRN & US & 1997-2004 & $(-1,1)$ & 475 & -2.95 & n.s. \\
\hline Prakash, Rangan, and Salandro (2011) & SSRN & US & $1997-2006$ & $(-1,1)$ & 1681 & -3.36 & $\begin{array}{l}\text { Calculated as the } \\
\text { samples of respect } \\
=-3.63 \% \text { ) and } 215\end{array}$ \\
\hline Wang, Chen, and Cheng (2011) & RQFA & US & $1978-2005$ & $(-1,0)$ & 3029 & -1.78 & $* * *$ \\
\hline Barclay, Fu, and Smith (2012) & SSRN & US & 1970-2006 & $(-1,1)$ & 4354 & -2.42 & n.r. \\
\hline Chaudhuri and Seo (2012) & IFMIM & US & $1994-2003$ & $(-1,1)$ & 2193 & -2.4 & n.r. \\
\hline Deng, Hrnjic, and Ong (2012) & SSRN & US & $1986-2009$ & $(-3,3)$ & 814 & -0.47 & n.r. \\
\hline Duca, Dutordoir, Veld, and Verwijmeren (2012) & JBF & US & 1984-2009 & $(-1,1)$ & 4885 & -2.45 & $\begin{array}{l}\text { Calculated as the } \\
\text { samples of respect } \\
=-2.343 \%), 1143 \\
\text { and } 163 \text { observati }\end{array}$ \\
\hline Dutordoir and Hodrick (2012) & SSRN & US & $1999-2008$ & $(0,0)$ & 343 & -1.76 & $* * *$ \\
\hline Floros and Sapp (2012) & $\mathrm{JBF}$ & US & $1995-2008$ & $(-2,2)$ & 6371 & 1.38 & n.r. \\
\hline Gokkaya and Roskelley (2012) & SSRN & US & $1996-2007$ & $(-1,1)$ & 2099 & -1.86 & $* * *$ \\
\hline Qian, Zhong, and Zhong (2012) & JFR & US & $1990-2007$ & $(-1,1)$ & 2000 & -2.1 & n.r. \\
\hline Zeidler, Mietzner, and Schiereck (2012) & $\mathrm{JCF}$ & US & $1980-2002$ & $(-1,1)$ & 2905 & -1.8 & $* * *$ \\
\hline
\end{tabular}




\begin{tabular}{|c|c|c|c|c|c|c|c|}
\hline Bradley and Yuan (2013) & $\mathrm{JCF}$ & US & $1997-2006$ & $(-1,1)$ & 1777 & -2.4 & $* * *$ \\
\hline Gustafson (2013) & SSRN & US & $2000-2011$ & $(0,1)$ & 1029 & 3.01 & $\begin{array}{l}\text { Calculated as the } \\
\text { samples of respect } \\
3.38 \% \text { ) and } 403 \text { ol }\end{array}$ \\
\hline Jiang, Stohs, and Xie (2013) & SSRN & US & $1970-2006$ & $(-1,1)$ & 1610 & -3.46 & n.r. \\
\hline Zhang (2013) & SSRN & US & 1970-2009 & $(0,1)$ & 5074 & -2.28 & $\begin{array}{l}\text { Calculated as the } \\
\text { samples of respect } \\
=-2.14 \%), 2030 \\
\text { and } 1522 \text { observat }\end{array}$ \\
\hline Brisker, Autore, Colak, and Peterson (2014) & JBF & US & 1993-2006 & $(-1,1)$ & 1284 & -2.68 & n.r. \\
\hline Cline, Garner, and Yore (2014) & $\mathrm{JCF}$ & US & 1979-2011 & $(-2,2)$ & 1152 & -1.62 & $* * *$ \\
\hline Cornett, Mehran, Pan, Phan, and Wei (2014) & SSRN & US & $2002-2011$ & $(-1,1)$ & 460 & -2.49 & n.r. \\
\hline Fich, Starks, and Yore (2014) & JFE & US & $1996-2006$ & $(-2,2)$ & 548 & -0.5 & $*$ \\
\hline Gokkaya and Highfield (2014) & $\mathrm{FM}$ & US & $1997-2009$ & $(-1,1)$ & 1032 & -2.62 & $* * *$ \\
\hline Hao (2014) & FM & US & $1984-2008$ & $(-1,1)$ & 2668 & -1.41 & n.r. \\
\hline Henderson and Zhao (2014) & $\mathrm{JCF}$ & US & $2000-2010$ & $(-1,0)$ & 83 & -7.85 & $* * *$ \\
\hline Kim and Purnanandam (2014) & $\mathrm{RF}$ & US & $1982-2006$ & $(0,1)$ & 4613 & -1.97 & n.r. \\
\hline Park (2014) & SSRN & US & $1995-2010$ & $(-1,1)$ & 2466 & -2.86 & $* * *$ \\
\hline Akhigbe and Whyte (2015) & $\mathrm{JCF}$ & US & $1996-2012$ & $(-1,1)$ & 2775 & -2.02 & $* * *$ \\
\hline Billett, Elkamhi, and Floros (2015) & JFI & US & $2001-2010$ & $(-2,2)$ & 1851 & 1.81 & $\begin{array}{l}\text { Calculated as the } \\
\text { samples of respect } \\
5.46 \% \text { ) and } 1108\end{array}$ \\
\hline Pinto-Gutierrez (2015) & SSRN & US & 2003-2012 & $(-1,1)$ & 917 & -2.8 & $* * *$ \\
\hline Autore and DeLisle (2016) & RCFS & US & $1990-2009$ & $(0,1)$ & 1416 & -2.12 & n.r. \\
\hline Boone, Floros, and Johnson (2016) & JFE & US & $1996-2013$ & $(-1,1)$ & 2231 & -3.19 & $\begin{array}{l}\text { Calculated as the } \\
\text { samples of respect } \\
=-3.36 \% \text { ) and } 88(\end{array}$ \\
\hline Duca (2016) & $\mathrm{JCF}$ & US & $1975-2007$ & $(-1,1)$ & 5371 & -2.22 & $* * *$ \\
\hline Ferreira and Laux (2016) & JFQA & US & $1990-2005$ & $(0,1)$ & 410 & -1.8 & St.dev $=0.06$ \\
\hline Golubov, Petmezas, and Travlos (2016) & $\mathrm{RF}$ & US & $1985-2009$ & $(-2,2)$ & 3212 & -3.16 & $* * *$ \\
\hline Holderness and Pontiff (2016) & JFE & US & 1983-2009 & $(-1,1)$ & 164 & 0 & n.s. \\
\hline Michaely, Rubin, and Vedrashko (2016) & JFE & US & $1995-2010$ & $(0,1)$ & 4492 & -2.2 & $* * *$ \\
\hline Walker, Yost, and Zhao (2016) & FM & US & $1995-2008$ & $(0,1)$ & 670 & -2.34 & n.r. \\
\hline Berkman, McKenzie, and Verwijmeren (2017) & $\mathrm{RF}$ & US & $2007-2011$ & $(0,1)$ & 339 & 2.22 & $* * *$ \\
\hline Deshmukh, Gamble, and Howe (2017) & $\mathrm{JCF}$ & US & $1988-2011$ & $(-1,1)$ & 6852 & -2.09 & $* * *$ \\
\hline Dutordoir, Strong, and Sun (2017) & SSRN & US & $2004-2013$ & $(0,1)$ & 934 & -4.591 & n.r. \\
\hline Lim, Schwert, and Weisbach (2017) & SSRN & US & $2001-2015$ & $(-1,1)$ & 2963 & 4 & $* * *$ \\
\hline Walker and $\mathrm{Wu}(2017)$ & SSRN & US & 1994-2001 & $(-3,3)$ & 2555 & -3.44 & $* * *$ \\
\hline Billett, Floros, and Garfinkel (2018) & JFQA & US & $2008-2011$ & $(-1,1)$ & 627 & -4.39 & $\begin{array}{l}\text { Calculated as the } \\
\text { samples of respect } \\
-3.74 \% \text { ) and } 495 \\
\end{array}$ \\
\hline Chan, Nayar, Singh, and Yu (2018) & $\mathrm{FM}$ & US & 1997-2004 & $(0,1)$ & 934 & -2.88 & $* * *$ \\
\hline Johnson, Kang, Masulis, and Yi (2018) & JFI & US & $1986-2005$ & $(-1,1)$ & 1946 & -3.14 & $\begin{array}{l}\text { Calculated as the } \\
\text { samples of respect } \\
4.15 \% \text { ) and } 1574\end{array}$ \\
\hline Holderness $(2018)^{(2)}$ & JFE & US & 1979-1997 & $(-1,1)$ & 594 & 1.91 & $\begin{array}{l}\text { Calculated as the } \\
\text { samples of respect } \\
3.55 \% \text { ) and } 388 \text { ol }\end{array}$ \\
\hline Chikolwa and Kim (2009) & SSRN & Australia & $2000-2008$ & $(-15,1)$ & 277 & -2.13 & $* * *$ \\
\hline
\end{tabular}




\begin{tabular}{|c|c|c|c|c|c|c|c|}
\hline Holderness (2018) & JFE & Australia & $1999-2004$ & $(-1,1)$ & 510 & 3.72 & $\begin{array}{l}\text { Calculated as the } \\
\text { samples of respect } \\
6.39 \% \text { ) and } 289 \text { o }\end{array}$ \\
\hline Pandes (2010) & JBF & Canada & $1993-2005$ & $(-1,0)$ & 748 & -0.54 & n.r. \\
\hline Maynes and Pandes (2011) & EFM & Canada & $1993-2005$ & $(-1,1)$ & 347 & 2.99 & $\begin{array}{l}\text { Calculated as the } \\
\text { samples of respect } \\
-6.46 \% \text { ) and } 231\end{array}$ \\
\hline Dong, Loncarski, ter Horst, and Veld (2012) & FM & Canada & $1998-2007$ & $(-1,1)$ & 1125 & -0.5 & n.s. \\
\hline Corby and Stohs (1998) & EJF & Ireland & $1987-1994$ & $(0,1)$ & 95 & -0.56 & n.s. \\
\hline Marsden (2000) & PBFJ & $\begin{array}{l}\text { New } \\
\text { Zealand }\end{array}$ & 1976-1984 & $(0,1)$ & 88 & -1.01 & $* * *$ \\
\hline Anderson, Rose, and Cahan (2006) & PBFJ & $\begin{array}{l}\text { New } \\
\text { Zealand } \\
\end{array}$ & $1990-2002$ & $(0,1)$ & 70 & 0.15 & n.s. \\
\hline Slovin, Sushka, and Lai (2000) & JFE & UK & $1986-1994$ & $(-1,0)$ & 366 & -1.88 & $\begin{array}{l}\text { Calculated as the } \\
\text { samples of respect } \\
1.5 \% \text { ), } 119 \text { observ } \\
\text { observations (CAI } \\
\text { observations (CAI }\end{array}$ \\
\hline Armitage (2002) & JBFA & UK & $1985-1996$ & $(-1,0)$ & 1008 & -0.96 & $* * *$ \\
\hline Korteweg and Renneboog (2003) & SSRN & UK & 1992-1999 & $(-1,1)$ & 52 & 0.53 & $\begin{array}{l}\text { Calculated as the } \\
\text { samples of respect } \\
1.8 \% \text { ) and } 14 \text { obse }\end{array}$ \\
\hline Iqbal (2008) & JBFA & UK & $1988-1998$ & $(-1,1)$ & 585 & -1.8 & $* * *$ \\
\hline Armitage and Capstaff (2009) & EJF & UK & $1991-1995$ & $(-1,0)$ & 318 & 1.55 & $* * *$ \\
\hline Armitage (2012) & EJF & UK & $2003-2006$ & $(-1,1)$ & 261 & -0.38 & $\begin{array}{l}\text { Calculated as the } \\
\text { samples of respec } \\
2.97 \% \text { ), } 134 \text { obser } \\
\text { observations (CA }\end{array}$ \\
\hline Dissanaike, Faasse, and Jayasekera (2014) & JIMF & UK & $2003-2012$ & $(-3,3)$ & 700 & -0.63 & n.s. \\
\hline Dionysiou (2015) & EJF & UK & $1998-2008$ & $(-1,1)$ & 322 & 2.22 & n.s. \\
\hline Silva and Bilinski (2015) & JBFA & UK & $1994-2007$ & $(-1,1)$ & 1678 & 0.36 & $\begin{array}{l}\text { Calculated as the } \\
\text { samples of respect } \\
-2.30 \%), 873 \text { obse } \\
558 \text { observations }\end{array}$ \\
\hline \multicolumn{8}{|l|}{ Network-oriented country studies } \\
\hline Huang, Zhao, and Mao (2009) & SSRN & China & $1998-2004$ & $(0,1)$ & 340 & -0.86 & $* * *$ \\
\hline Fonseka, Colombage, and Tian (2014) & IFMIM & China & $2006-2010$ & $(-3,0)$ & 218 & 1.2 & $* * *$ \\
\hline Huang, Uchida, and Zha (2016) & $\mathrm{JCF}$ & China & $2006-2014$ & $(0,1)$ & 101 & -1.13 & $* * *$ \\
\hline Liu, Akbar, Shah, Zhang, and Pang (2016) & JBFA & China & $1991-2010$ & $(0,0)$ & 1588 & -0.56 & $\begin{array}{l}\text { Calculated as the } \\
\text { samples of respect } \\
-0.63 \%), 239 \text { obse } \\
375 \text { observations }\end{array}$ \\
\hline Chen (2017) & $\mathrm{AF}$ & China & $1999-2010$ & $(-1,1)$ & 631 & 2.86 & $* * *$ \\
\hline Huang, Uchida, and Zha (2017) & SSRN & China & $2006-2014$ & $(0,1)$ & 818 & 1.68 & $* * *$ \\
\hline $\mathrm{He}, \mathrm{Li}, \mathrm{Lu}$, and Chong (2018) & IRF & China & $2005-2013$ & $(-1,1)$ & 972 & 21.1 & $* * *$ \\
\hline Gajewski and Ginglinger (2002) & EFR & France & $1986-1996$ & $(0,1)$ & 219 & -0.8 & n.r. \\
\hline Gajewski, Ginglinger, and Lasfer (2007) & $\mathrm{JCF}$ & France & $1986-2000$ & $(0,1)$ & 284 & -0.54 & $\begin{array}{l}\text { Calculated as the } \\
\text { samples of respect } \\
-0.52 \%) \text { and } 41 \text { ob }\end{array}$ \\
\hline Koenig-Matsoukis (2012) & SSRN & France & $1995-2006$ & $(0,0)$ & 121 & -0.58 & n.s. \\
\hline Ginglinger, Matsoukis, and Riva (2013) & JBFA & France & $1986-2000$ & $(-1,0)$ & 178 & -0.73 & n.r. \\
\hline Baruch, Panayides, and Venkataraman (2016) & JFE & France & 2003 & $(0,1)$ & 36 & 0.32 & $\begin{array}{l}\text { Calculated as the } \\
\text { samples of respect } \\
3.41 \% \text { ) and } 14 \text { ob }\end{array}$ \\
\hline Bessler, Drobetz, Seim, and Zimmermann (2016) & EFM & Germany & $1998-2002$ & $(-1,1)$ & 71 & 3.53 & $*$ \\
\hline Tsangarakis (1996) & FM & Greece & $1981-1990$ & $(-1,0)$ & 49 & 3.97 & $* * *$ \\
\hline
\end{tabular}




\begin{tabular}{|c|c|c|c|c|c|c|c|}
\hline Espenlaub, Siougle, and Strong (2008) & SSRN & Greece & $1992-1999$ & $(-1,1)$ & 129 & -1.37 & $* * *$ \\
\hline Wu and Wang (2002) & SSRN & Hong Kong & $1989-1997$ & $(-1,0)$ & 180 & -3.37 & $* * *$ \\
\hline Wu, Wang, and Yao (2005) & $\mathrm{RF}$ & Hong Kong & $1989-1997$ & $(-1,0)$ & 405 & 1.94 & $\begin{array}{l}\text { Calculated as the } \\
\text { samples of respect } \\
1.97 \% \text { ) and } 306 \text { ol }\end{array}$ \\
\hline Ching, Firth, and Rui (2006) & PBFJ & Hong Kong & $1993-1998$ & $(-1,0)$ & 506 & 1.09 & $* * *$ \\
\hline Lee, Poon, and Sinnakkannu (2014) & PBFJ & Hong Kong & $2003-2011$ & $(-1,1)$ & 267 & -0.25 & $\begin{array}{l}\text { Calculated as the } \\
\text { samples of respect } \\
-11.9 \% \text { ) and } 157\end{array}$ \\
\hline Lee, Poon, and Sinnakkannu (2017) & IRF & Hong Kong & $2003-2012$ & $(0,1)$ & 361 & -12.82 & $\begin{array}{l}\text { Calculated as the } \\
\text { samples of respect } \\
-15.85 \% \text { ) and } 144\end{array}$ \\
\hline Marisetty, Marsden, and Veeraraghavan (2008) & PBFJ & India & $1997-2005$ & $(-1,0)$ & 67 & 0.32 & n.s. \\
\hline Hauser, Kraizberg, and Dahan (2003) & JCF & Israel & $1989-1997$ & $(-5,0)$ & 76 & 0.91 & $\begin{array}{l}\text { Calculated as the } \\
\text { samples of respect } \\
0.57 \% \text { ) and } 29 \text { ob }\end{array}$ \\
\hline Bigelli (1998) & EFM & Italy & 1980-1994 & $(-1,1)$ & 82 & 0.79 & n.s. \\
\hline Kato and Schallheim (1993) & PBFJ & Japan & 1974-1988 & $(0,1)$ & 136 & 2.5 & $\begin{array}{l}\text { Calculated as the } \\
\text { samples of respect } \\
4.98 \% \text { ) and } 60 \mathrm{ob}\end{array}$ \\
\hline Kang and Stulz (1996) & RFS & Japan & $1985-1991$ & $(-1,1)$ & 282 & 1.26 & $\begin{array}{l}\text { Calculated as the } \\
\text { samples of respect } \\
0.45 \% \text { ), } 69 \text { observ } \\
\text { observations (CAI }\end{array}$ \\
\hline Cooney, Kato, and Schallheim (2003) & RFS & Japan & 1974-1993 & $(-1,1)$ & 544 & 0.63 & $* * *$ \\
\hline Kato and Suzuki (2012) & SSRN & Japan & 1994-2009 & $(-1,1)$ & 830 & -2.35 & $* * *$ \\
\hline Shimizu and $\mathrm{Xu}(2014)$ & SSRN & Japan & $2005-2011$ & $(-1,1)$ & 25 & -4.31 & $* * *$ \\
\hline Morita (2016) & SSRN & Japan & $2010-2013$ & $(0,0)$ & 45 & -1.92 & $\begin{array}{l}\text { Calculated as the } \\
\text { samples of respect } \\
2.20 \% \text { ) and } 21 \text { ob }\end{array}$ \\
\hline Salamudin, Ariff, and Nassir (1999) & PBFJ & Malaysia & 1980-1995 & $(0,1)$ & 72 & -0.91 & n.s. \\
\hline De Jong and Veld (2001) & $\mathrm{JBF}$ & Netherlands & $1977-1996$ & $(-1,1)$ & 84 & -1.07 & $*$ \\
\hline Kabir and Roosenboom (2003) & $\mathrm{JCF}$ & Netherlands & 1984-1999 & $(0,1)$ & 58 & -2.79 & $* * *$ \\
\hline Bohren, Eckbo, and Michalsen (1997) & JFE & Norway & 1980-1993 & $(-1,0)$ & 188 & 0.47 & $* *$ \\
\hline Krakstad and Molnar (2015) & SSRN & Norway & $1992-2010$ & $(-1,1)$ & 1934 & -2 & n.s. \\
\hline Duong, Singh, and Tan (2015) & JBFA & Singapore & $1997-2007$ & $(-1,1)$ & 189 & 0.35 & $\begin{array}{l}\text { Calculated as the } \\
\text { samples of respect } \\
2.00 \% \text { ) and } 52 \text { ob }\end{array}$ \\
\hline Martin-Ugedo (2003) & JBFA & Spain & $1989-1997$ & $(-1,0)$ & 57 & -1.25 & $* * *$ \\
\hline Cronqvist and Nilsson (2005) & JFE & Sweden & 1986-1999 & $(-1,1)$ & 296 & 3.54 & $\begin{array}{l}\text { Calculated as the } \\
\text { samples of respect } \\
0.37 \% \text { ) and } 136 \text { ol }\end{array}$ \\
\hline Lin, You, and Lin (2008) & JBFA & Taiwan & $1996-2001$ & $(-3,0)$ & 293 & -0.4 & $* * *$ \\
\hline Wang, Chen, and Huang (2008) & RPBFMP & Taiwan & $1996-2006$ & $(0,1)$ & 385 & 0.28 & $\begin{array}{l}\text { Calculated as the } \\
(0.157 \%)\end{array}$ \\
\hline Twu (2010) & RPBFMP & Taiwan & $1985-2004$ & $(-1,0)$ & 1018 & -0.09 & $\begin{array}{l}\text { Calculated as the } \\
\text { samples of respect } \\
0.0396 \text { ) and } 8090\end{array}$ \\
\hline Liang and Jang (2013) & QREF & Taiwan & $2002-2008$ & $(-3,0)$ & 302 & 1.42 & $* * *$ \\
\hline Cheng, Wang, and Chen (2014) & RPBFMP & Taiwan & $2003-2010$ & $(0,1)$ & 221 & 0.88 & $* * *$ \\
\hline Yeh, Shu, and Kao (2015) & RPBFMP & Taiwan & $2002-2007$ & $(-1,1)$ & 213 & 0.04 & n.s. \\
\hline \multicolumn{8}{|l|}{ International studies } \\
\hline Fauver, Loureiro, and Taboada (2017) & $\mathrm{JCF}$ & $\mathrm{EU}$ & $1999-2012$ & $(-1,1)$ & 1125 & -1.4 & $* * *$ \\
\hline Gropp, Mosk, Ongena, and Wix (2017) & SSRN & $\mathrm{EU}$ & $2009-2013$ & $(-1,1)$ & 79 & -2.26 & $\begin{array}{l}\text { Calculated as the } \\
\text { samples of respect } \\
1.72 \% \text { ) and } 32 \text { ob }\end{array}$ \\
\hline
\end{tabular}




\begin{tabular}{|c|c|c|c|c|c|c|c|}
\hline Higgins, Howton, and Howton (2002) & FR & International & 1992-1997 & $(0,0)$ & 162 & -0.49 & n.r. \\
\hline Errunza and Miller (2003) & JBF & International & 1981-1996 & $(-1,1)$ & 123 & -0.68 & n.r. \\
\hline Massa, Vermaelen, and Xu (2013) & SSRN & International & $1995-2008$ & $(-1,1)$ & 12639 & 1.83 & $* * *$ \\
\hline Massa, Mataigne, Vermaelen, and Xu (2016) & SSRN & International & $1995-2011$ & $(-1,1)$ & 37767 & -0.77 & $\begin{array}{l}\text { Calculated as the } \\
\text { samples of respect } \\
=-1.02 \% \text { ) and } 15 \\
0.42 \% \text { ). }\end{array}$ \\
\hline Dahiya, Klapper, Parthasarathy, and Singer (2017) & JCF & International & 2000-2009 & $(-1,1)$ & 2366 & 1.2 & $\begin{array}{l}\text { Calculated as the } \\
\text { samples of respect } \\
3.41 \% \text { ) and } 1910\end{array}$ \\
\hline Li, Liu, and Veld (2017) & SSRN & International & 2001-2012 & $(-1,1)$ & 1307 & -0.74 & $* * *$ \\
\hline
\end{tabular}

(1) $* * *$ significant at the $1 \%$-level, $* *$ significant at the $5 \%$-level, * significant at the $10 \%$-level (2-tail tests), n.s. $=$ not significant on at least $10 \%$ level; n.r. = significance is not reported by the authors.

(2) Holderness (2018) reported separate results for Australia and the US. 
Table 3: Cumulative abnormal returns around SEO announcements

This table reports descriptive statistics for cumulative abnormal returns for both published and non-published studies on the effects of SEO announcements on stock prices for the period until December 31, 2017. The (sub)samples of studies include papers published in the top 26 Finance journals as specified by Heck and Cooley (2009) with the addition of papers published in Accounting and Finance, Critical Finance Review, International Review of Finance, International Review of Financial Analysis, Journal of International Financial Markets, Institutions and Money, Journal of International Money and Finance, Journal of Business, Review of Corporate Finance Studies, Review of Asset Pricing Studies, Review of Finance (European Finance Review), European Financial Management, and European Journal of Finance, as well as working papers that are included in the library of the Social Sciences Research Network (SSRN). $p$-values are reported for the $t$-test of equal means, Wilcoxon Signed Rank Test of median equal to zero, and for the Kruskal-Wallis test of equal medians between U.S. studies and non-U.S. studies as well as studies published in journals and SSRN working papers.

\begin{tabular}{|c|c|c|c|c|c|}
\hline & All studies & U.S. studies & $\begin{array}{l}\text { Non-U.S. } \\
\text { studies }\end{array}$ & $\begin{array}{l}\text { Published } \\
\text { papers }\end{array}$ & Working papers \\
\hline Mean & -0.98 & -1.48 & -0.03 & -0.86 & -1.51 \\
\hline Standard deviation & 2.71 & 1.83 & 3.71 & 2.86 & 1.87 \\
\hline$t$-statistics & -5.13 & -9.25 & -0.06 & -3.85 & -4.92 \\
\hline $\begin{array}{l}p \text {-value of t-test of equal means (U.S. vs } \\
\text { Non-U.S., Published vs WP) }\end{array}$ & & & 0.003 & & 0.09 \\
\hline Median & -1.39 & -1.86 & -0.45 & -1.18 & -2 \\
\hline $\begin{array}{l}p \text {-value of the One-Sample Wilcoxon } \\
\text { Signed Rank Test of median equal to zero }\end{array}$ & 0 & 0 & 0.54 & 0 & 0 \\
\hline $\begin{array}{l}p \text {-value of Kruskal-Wallis test of equal } \\
\text { medians (U.S. vs Non-U.S., Published vs } \\
\text { WP) }\end{array}$ & & & 0 & & 0.05 \\
\hline Minimum & -12.82 & -7.85 & -12.82 & -12.82 & -4.59 \\
\hline Maximum & 21.1 & 4 & 21.1 & 21.1 & 4 \\
\hline Number of studies & 199 & 131 & 68 & 162 & 37 \\
\hline Number of sub-samples & 861 & 551 & 310 & 643 & 218 \\
\hline Number of announcements within studies & 275,103 & 197,578 & 77,525 & 170,583 & 104,520 \\
\hline $\begin{array}{l}\text { Number of announcements within studies } \\
\text { (double counted) }\end{array}$ & 529,990 & 407,246 & 122,744 & 292,181 & 237,809 \\
\hline
\end{tabular}


Table 4: Meta-analysis regression results using $C A R s$ as dependent variables

The dependent variables in these models are Cumulative Abnormal Returns (CARs) associated with the SEO announcements. Panel A reports the results from all studies, Panel B reports the results from U.S. studies only, and Panel C reports the results of non-U.S. studies. The independent variables are: Rights issue ( $=1$ for rights issues, $=0$ otherwise), Private issue ( $=1$ for private issues, $=0$ otherwise), Warrants $(=1$ for combined shares and warrants issues, $=0$ otherwise), Post 2000 sample ( $=1$ for equity issues after $2000 ;=0$ otherwise), Low asymmetric information ( $=1$ for companies with low asymmetric information, $=0$ otherwise), Insider ( $=1$ for issues with a presence of insider information, $=0$ otherwise), Industrial Company ( $=1$ for industrial companies, $=0$ otherwise), Financial Company ( $=1$ for financial companies, $=0$ otherwise), Dividend paying stock ( $=1$ for dividend-paying stocks, $=0$ otherwise), SEO within 3 yrs of IPO $(=1$ for SEOs announced within 3 years of IPO, $=0$ otherwise), $S E O$ for debt reduction ( $=1$ for SEOs used to reduce company debt, $=0$ otherwise), SEO for Investment ( $=1$ for SEOs used to finance new investments, $=0$ otherwise), other SEO reasons are used as the base case; Dual-class SEO ( 1 for companies with dual-class share structure, $=0$ otherwise); Secondary SEO (=1 for SEOs where secondary shares are sold, $=0$ otherwise); Network-oriented country (=1 for studies using data from network-oriented countries, $=0$ otherwise), Medium and Low investor protection $(=1$ if study is using data from country with medium or low investor protection level as described in La Porta, Lopez-de-Silanes, Shleifer, and Vishny (1997), =0 otherwise; countries with high level of protection are used as benchmark); U.S. ( $=1$ for studies based on data from U.S., $=0$ otherwise), Top 4 journal ( $=1$ for studies published in top 4 Finance journals, i.e. Journal of Finance, Journal of Financial Economics, Review of Financial Studies, Journal of Financial and Quantitative Analysis, $=0$ otherwise), Top 38 journal (=1 for studies published in Top 26 journals as specified in Heck and Cooley (2009) plus Accounting and Finance, Critical Finance Review, European Financial Management, International Review of Finance, International Review of Financial Analysis, Journal of International Financial Markets, Institutions and Money, Journal of International Money and Finance, European Journal of Finance, Journal of Business $\backslash$, Review of Asset Pricing Studies, Review of Corporate Finance Studies, and Review of Finance, =0 otherwise). 2-day (=1 for study samples that report 2-day event window around the announcement date, $=0$ otherwise), Event window other than 2-day or 3day ( $=1$ for study samples that report event windows other than 2-day or 3-day windows around the announcement day, $=0$ otherwise). Robust standard errors are reported in parentheses. Models are OLS regressions with Rogers (1983) clustered errors with countries used as clusters. $* * *$ Significant at the $1 \%$-level, ** significant at the $5 \%$-level, * significant at the $10 \%$-level (2-tail tests).

\begin{tabular}{|c|c|c|c|c|c|c|c|c|}
\hline \multirow{3}{*}{$\begin{array}{l}\text { Dependent variable } \\
\text { Independent variable }\end{array}$} & \multicolumn{8}{|c|}{ Mean Cumulative Abnormal Return } \\
\hline & \multicolumn{4}{|c|}{ Panel A: All studies } & \multicolumn{2}{|c|}{ Panel B: U.S. studies } & \multicolumn{2}{|c|}{$\begin{array}{c}\text { Panel C: Non-U.S. } \\
\text { studies }\end{array}$} \\
\hline & $(1)$ & $(2)$ & (3) & $(4)$ & $(5)$ & $(6)$ & $(7)$ & $(8)$ \\
\hline \multirow[t]{2}{*}{ Rights issue } & $-1.95 * *$ & $-1.96 * *$ & $-1.82 * *$ & $-2.09 * *$ & $1.16^{* * *}$ & $1.05 * * *$ & $-1.89^{*}$ & $-2.12 *$ \\
\hline & $(0.85)$ & $(0.87)$ & $(0.88)$ & $(0.89)$ & $(0.32)$ & $(0.31)$ & $(0.97)$ & $(1.05)$ \\
\hline \multirow[t]{2}{*}{ U.S.*Rights issue } & $3.11 * * *$ & $3.13 * * *$ & $2.97 * * *$ & $3.08 * * *$ & & & & \\
\hline & $(0.85)$ & $(0.88)$ & $(0.88)$ & $(0.87)$ & & & & \\
\hline \multirow[t]{2}{*}{ Private issue } & $2.35^{* * *}$ & $2.35^{* * *}$ & $2.36 * * *$ & $2.40 * * *$ & $2.81 * * *$ & $2.85 * * *$ & $2.33 * * *$ & $2.42 * * *$ \\
\hline & $(0.69)$ & $(0.69)$ & $(0.74)$ & $(0.66)$ & $(0.38)$ & $(0.38)$ & $(0.66)$ & $(0.63)$ \\
\hline \multirow[t]{2}{*}{ U.S.*Private issue } & 0.48 & 0.47 & 0.48 & 0.48 & & & & \\
\hline & $(0.71)$ & $(0.70)$ & $(0.75)$ & $(0.67)$ & & & & \\
\hline \multirow[t]{2}{*}{ Warrants } & 0.57 & 0.57 & $0.64 *$ & $0.88^{* *}$ & 0.88 & 1.04 & 0.43 & 0.89 \\
\hline & $(0.39)$ & $(0.40)$ & $(0.33)$ & $(0.42)$ & $(0.86)$ & $(0.85)$ & $(0.85)$ & $(1.02)$ \\
\hline \multirow[t]{2}{*}{ Post 2000 sample } & -0.94 & -0.98 & -0.95 & -0.85 & 0.25 & 0.36 & -1.02 & -0.87 \\
\hline & $(1.26)$ & $(1.26)$ & $(1.23)$ & $(1.26)$ & $(0.67)$ & $(0.67)$ & $(1.30)$ & $(1.28)$ \\
\hline \multirow[t]{2}{*}{ U.S.*Post 2000 sample } & 1.23 & 1.27 & 1.22 & 1.34 & & & & \\
\hline & $(1.29)$ & $(1.29)$ & $(1.27)$ & $(1.32)$ & & & & \\
\hline \multirow[t]{2}{*}{ Low asymmetric information } & -0.26 & -0.27 & -0.26 & -0.26 & -0.30 & -0.33 & 0.36 & 0.61 \\
\hline & $(0.16)$ & $(0.16)$ & $(0.16)$ & $(0.19)$ & $(0.25)$ & $(0.24)$ & $(0.71)$ & $(0.86)$ \\
\hline \multirow[t]{2}{*}{ Insider } & -1.21 & -1.24 & -1.18 & -1.26 & $-0.52 * *$ & $-0.76^{* *}$ & -1.88 & -1.73 \\
\hline & $(0.96)$ & $(0.97)$ & $(0.84)$ & $(0.92)$ & $(0.23)$ & $(0.32)$ & $(1.31)$ & $(1.47)$ \\
\hline \multirow[t]{2}{*}{ Industrial Company } & $-0.45^{* *}$ & $-0.46 * * *$ & $-0.41 * *$ & $-0.43 *$ & $-0.59 * * *$ & $-0.62 * * *$ & -0.44 & 0.17 \\
\hline & $(0.16)$ & $(0.16)$ & $(0.18)$ & $(0.25)$ & $(0.22)$ & $(0.21)$ & $(0.80)$ & $(0.88)$ \\
\hline \multirow[t]{2}{*}{ Financial Company } & 0.19 & 0.18 & 0.18 & 0.36 & 0.10 & 0.24 & -0.33 & -0.61 \\
\hline & $(0.25)$ & $(0.25)$ & $(0.23)$ & $(0.27)$ & $(0.25)$ & $(0.25)$ & $(1.03)$ & $(0.88)$ \\
\hline \multirow[t]{2}{*}{ Dividend paying stock } & $0.20 * *$ & $0.20 * *$ & 0.14 & $0.49 * * *$ & 0.22 & 0.37 & -0.30 & 0.12 \\
\hline & $(0.09)$ & $(0.09)$ & $(0.12)$ & $(0.15)$ & $(0.31)$ & $(0.31)$ & $(0.73)$ & $(0.64)$ \\
\hline \multirow[t]{2}{*}{ SEO within 3 yrs of IPO } & $-0.62 * * *$ & $-0.62 * * *$ & $-0.59 * * *$ & $-0.53 * * *$ & -0.57 & -0.52 & & \\
\hline & $(0.05)$ & $(0.05)$ & $(0.04)$ & $(0.05)$ & $(0.36)$ & $(0.36)$ & & \\
\hline \multirow[t]{2}{*}{ SEO for debt reduction } & $-0.77 *$ & $-0.80^{*}$ & -0.57 & $-0.85 * *$ & $-2.49 * * *$ & $-2.31 * * *$ & $-0.48 * *$ & $-0.68 * * *$ \\
\hline & $(0.44)$ & $(0.43)$ & $(0.41)$ & $(0.36)$ & $(0.15)$ & $(0.16)$ & $(0.19)$ & $(0.21)$ \\
\hline
\end{tabular}




\begin{tabular}{|c|c|c|c|c|c|c|c|c|}
\hline SEO for investment & $\begin{array}{c}0.83 \\
(0.68)\end{array}$ & $\begin{array}{c}0.80 \\
(0.67)\end{array}$ & $\begin{array}{c}0.99 \\
(0.61)\end{array}$ & $\begin{array}{c}0.81 \\
(0.58)\end{array}$ & $\begin{array}{l}-0.03 \\
(0.22)\end{array}$ & $\begin{array}{c}0.15 \\
(0.23)\end{array}$ & $\begin{array}{c}1.12 \\
(0.66)\end{array}$ & $\begin{array}{c}0.92 \\
(0.59)\end{array}$ \\
\hline Dual-class firm SEO & $\begin{array}{l}-0.08 \\
(0.13)\end{array}$ & $\begin{array}{l}-0.08 \\
(0.14)\end{array}$ & $\begin{array}{l}-0.05 \\
(0.13)\end{array}$ & $\begin{array}{c}0.01 \\
(0.13)\end{array}$ & $\begin{array}{c}0.03 \\
(0.35)\end{array}$ & $\begin{array}{c}0.08 \\
(0.32)\end{array}$ & & \\
\hline Secondary share SEO & $\begin{array}{c}-1.05^{* * *} \\
(0.12)\end{array}$ & $\begin{array}{c}-1.05^{* * *} \\
(0.12)\end{array}$ & $\begin{array}{c}-1.07 * * * \\
(0.13)\end{array}$ & $\begin{array}{c}-1.11^{* * *} \\
(0.13)\end{array}$ & $\begin{array}{c}-0.97 * * * \\
(0.31)\end{array}$ & $\begin{array}{c}-1.00 * * * \\
(0.34)\end{array}$ & & \\
\hline Network-oriented country & & $\begin{array}{l}-0.16 \\
(0.39)\end{array}$ & & & & & & \\
\hline High investor protection & & & $\begin{array}{l}-0.57 \\
(0.47)\end{array}$ & & & & & \\
\hline Two-day event window & $\begin{array}{l}-0.30 \\
(0.24)\end{array}$ & $\begin{array}{l}-0.30 \\
(0.24)\end{array}$ & $\begin{array}{l}-0.28 \\
(0.22)\end{array}$ & $\begin{array}{l}-0.41 \\
(0.29)\end{array}$ & $\begin{array}{l}-0.05 \\
(0.18)\end{array}$ & $\begin{array}{l}-0.09 \\
(0.18)\end{array}$ & $\begin{array}{c}-0.86^{* *} \\
(0.36)\end{array}$ & $\begin{array}{c}-1.12 * * * \\
(0.33)\end{array}$ \\
\hline $\begin{array}{l}\text { Event window other than 2-day or 3- } \\
\text { day }\end{array}$ & $\begin{array}{l}0.65^{* *} \\
(0.26)\end{array}$ & $\begin{array}{l}0.66^{* *} \\
(0.26)\end{array}$ & $\begin{array}{l}0.61 * * \\
(0.29)\end{array}$ & $\begin{array}{c}0.78 * * * \\
(0.21)\end{array}$ & $\begin{array}{c}1.04 * * * \\
(0.22)\end{array}$ & $\begin{array}{c}1.06^{* * *} \\
(0.22)\end{array}$ & $\begin{array}{c}0.15 \\
(0.46)\end{array}$ & $\begin{array}{c}0.50 \\
(0.43)\end{array}$ \\
\hline Intercept & $\begin{array}{l}-0.07 \\
(0.61)\end{array}$ & $\begin{array}{l}-0.01 \\
(0.65)\end{array}$ & $\begin{array}{c}0.14 \\
(0.61)\end{array}$ & $\begin{array}{l}-0.07 \\
(0.61)\end{array}$ & $\begin{array}{c}-2.11 * * * \\
(0.17)\end{array}$ & $\begin{array}{c}-2.12 * * * \\
(0.17)\end{array}$ & $\begin{array}{c}0.16 \\
(1.28)\end{array}$ & $\begin{array}{c}0.16 \\
(1.34)\end{array}$ \\
\hline
\end{tabular}


Table 5: Meta-analysis regression results using $t$-statistics as dependent variables

The dependent variables in these regressions are $t$-statistics reported for the Cumulative Abnormal Returns (CARs) associated with the SEO announcements. Panel A reports the results from all studies, Panel B reports the results from U.S. studies only, and Panel C reports the results of non-U.S. studies. Heteroskedasticity consistent errors based on studies reporting $t$-statistics of event window mean CARs. The independent variables are: Rights issue ( $=1$ for rights issues, $=0$ otherwise), Private issue ( $=1$ for private issues, $=0$ otherwise), Warrants ( $=1$ for combined shares and warrants issues, $=0$ otherwise), Post 2000 sample ( $=1$ for equity issues after $2000 ;=0$ otherwise), Low asymmetric information ( $=1$ for companies with low asymmetric information, $=0$ otherwise), ), Insider (=1 for issue with a presence of insider information, $=0$ otherwise), Industrial Company $(=1$ for industrial companies, $=0$ otherwise), Financial Company $(=1$ for financial companies, $=0$ otherwise), Dividend paying stock (=1 for dividend-paying stocks, $=0$ otherwise), SEO within 3 yrs of IPO (=1 for SEOs announced within 3 years of IPO, $=0$ otherwise), SEO for debt reduction ( $=1$ for SEOs used to reduce company debt, $=0$ otherwise), $S E O$ for Investment ( $=1$ for SEOs used to finance new investments, $=0$ otherwise), other SEO reasons are used as the base case; Dual-class SEO (=1 for companies with dual-class share structure, $=0$ otherwise); Secondary SEO (=1 for SEOs where secondary shares are sold, $=0$ otherwise); Network-oriented country ( $=1$ for studies using data from network-oriented countries, $=0$ otherwise), Medium and low investor protection ( $=1$ if study is using data from country with medium or low investor protection level as described in La Porta, Lopez-de-Silanes, Shleifer, and Vishny (1997), =0 otherwise; countries with high level of protection are used as benchmark); U.S. (=1 for studies based on data from U.S., $=0$ otherwise), Top 4 journal ( $=1$ for studies published in Top 4 Finance journals, i.e. Journal of Finance, Journal of Financial Economics, Review of Financial Studies, Journal of Financial and Quantitative Analysis, =0 otherwise), Top 38 journal (=1 for studies published in Top 26 as specified in Heck and Cooley (2009) plus Accounting and Finance, Critical Finance Review, European Financial Management, International Review of Finance, International Review of Financial Analysis, Journal of International Financial Markets, Institutions and Money, Journal of International Money and Finance, European Journal of Finance, Journal of Business, Review of Asset Pricing Studies, Review of Corporate Finance Studies, and Review of Finance, =0 otherwise). 2day ( $=1$ for study samples that report 2-day event window around the announcement date, $=0$ otherwise), Event window other than 2-day or 3-day (=1 for study samples that report event windows other than 2-day or 3-day windows around the announcement day, =0 otherwise). Robust standard errors are reported in parentheses. Models are OLS regressions with Rogers (1983) clustered errors with clusters based on the countries.

*** Significant at the $1 \%$-level, ** significant at the 5\%-level, * significant at the $10 \%$-level (2-tail tests).

Dependent variable $t$-statistics of Cumulative Abnormal Return

\begin{tabular}{|c|c|c|c|c|c|c|c|c|}
\hline \multirow[b]{2}{*}{ Independent variable } & \multicolumn{4}{|c|}{ Panel A: All studies } & \multicolumn{2}{|c|}{ Panel B: U.S. studies } & \multicolumn{2}{|c|}{ Panel C: Non-U.S. studies } \\
\hline & $(1)$ & $(2)$ & (3) & (4) & $(5)$ & $(6)$ & $(7)$ & $(8)$ \\
\hline \multirow[t]{2}{*}{ Rights issue } & $-4.07 *$ & $-4.15^{*}$ & -3.99 & $-4.53 *$ & $6.43^{* * *}$ & $5.51 * * *$ & $-5.03 * *$ & $-5.23 * *$ \\
\hline & $(2.26)$ & $(2.26)$ & $(2.39)$ & $(2.45)$ & $(1.55)$ & $(1.45)$ & $(2.14)$ & $(2.39)$ \\
\hline \multirow[t]{2}{*}{ U.S.*Rights issue } & $9.89 * * *$ & $9.98 * * *$ & $9.82 * * *$ & $9.81 * * *$ & & & & \\
\hline & $(2.22)$ & $(2.23)$ & $(2.35)$ & $(2.37)$ & & & & \\
\hline \multirow[t]{2}{*}{ Private issue } & 1.76 & $1.78^{*}$ & 1.74 & $2.06^{*}$ & $6.30 * * *$ & $6.89 * * *$ & 0.75 & 0.94 \\
\hline & $(1.04)$ & $(1.00)$ & $(1.07)$ & $(1.04)$ & $(0.79)$ & $(0.88)$ & $(0.73)$ & $(0.73)$ \\
\hline \multirow[t]{2}{*}{ U.S.*Private issue } & $4.99 * * *$ & $4.94 * * *$ & $5.03 * * *$ & $5.13 * * *$ & & & & \\
\hline & $(1.11)$ & $(1.05)$ & $(1.16)$ & $(1.05)$ & & & & \\
\hline \multirow[t]{2}{*}{ Warrants } & $2.74 * *$ & $2.73 * *$ & $2.77 * *$ & $3.99 * *$ & $5.20 * * *$ & $6.60 * * *$ & 2.41 & 2.94 \\
\hline & $(1.18)$ & $(1.20)$ & $(1.13)$ & $(1.62)$ & $(1.16)$ & $(1.45)$ & $(1.82)$ & $(2.41)$ \\
\hline \multirow[t]{2}{*}{ Post 2000 sample } & -0.42 & -0.55 & -0.39 & 0.27 & $3.26^{*}$ & $3.84 * *$ & 0.29 & 0.72 \\
\hline & $(0.64)$ & $(0.64)$ & $(0.62)$ & $(0.82)$ & $(1.70)$ & $(1.71)$ & $(0.70)$ & $(0.93)$ \\
\hline \multirow[t]{2}{*}{ U.S.*Post 2000 sample } & $2.73 * * *$ & $2.86^{* * *}$ & $2.65 * * *$ & $2.64 * *$ & & & & \\
\hline & $(0.94)$ & $(0.91)$ & $(0.91)$ & $(0.93)$ & & & & \\
\hline \multirow[t]{2}{*}{$\begin{array}{l}\text { Low asymmetric } \\
\text { information }\end{array}$} & -1.16 & -1.23 & -1.22 & -1.36 & 0.94 & -0.85 & -0.64 & -0.22 \\
\hline & $(1.34)$ & $(1.36)$ & $(1.39)$ & $(1.32)$ & $(3.43)$ & $(3.41)$ & $(2.03)$ & $(2.44)$ \\
\hline \multirow[t]{2}{*}{ Insider } & -0.55 & -0.63 & -0.47 & -0.92 & $4.45^{* *}$ & 2.71 & $-3.07 * *$ & $-2.92 *$ \\
\hline & $(2.65)$ & $(2.71)$ & $(2.57)$ & $(2.02)$ & $(1.94)$ & $(1.91)$ & $(1.43)$ & $(1.47)$ \\
\hline \multirow[t]{2}{*}{ Industrial Company } & $-4.13 * * *$ & $-4.15 * * *$ & $-4.12 * * *$ & $-4.27 * * *$ & $-4.08 * * *$ & $-4.26 * * *$ & & \\
\hline & $(0.21)$ & $(0.21)$ & $(0.23)$ & $(0.21)$ & $(1.42)$ & $(1.33)$ & & \\
\hline \multirow[t]{2}{*}{ Financial Company } & $2.04 * *$ & $2.06 * *$ & $2.00 * *$ & $2.39 * *$ & $2.68 *$ & $3.74 * *$ & $3.40 *$ & 2.85 \\
\hline & $(0.79)$ & $(0.79)$ & $(0.75)$ & $(1.06)$ & $(1.58)$ & $(1.59)$ & $(1.94)$ & $(1.84)$ \\
\hline \multirow[t]{2}{*}{ Dividend paying stock } & $3.33 * * *$ & $3.31 * * *$ & $3.29 * * *$ & $4.36 * * *$ & $4.91 * * *$ & $5.95 * * *$ & -0.45 & 0.04 \\
\hline & $(1.02)$ & $(1.03)$ & $(1.05)$ & $(1.11)$ & $(1.10)$ & $(1.27)$ & $(1.61)$ & $(1.65)$ \\
\hline \multirow[t]{2}{*}{ SEO within 3 yrs of IPO } & $-1.63 * * *$ & $-1.62 * * *$ & $-1.62 * * *$ & $-0.99 * * *$ & -1.30 & -0.53 & & \\
\hline & $(0.23)$ & $(0.24)$ & $(0.23)$ & $(0.30)$ & $(1.44)$ & $(1.35)$ & & \\
\hline
\end{tabular}




\begin{tabular}{|c|c|c|c|c|c|c|c|c|}
\hline SEO for debt reduction & $\begin{array}{c}0.97 \\
(1.78)\end{array}$ & $\begin{array}{c}0.88 \\
(1.81)\end{array}$ & $\begin{array}{c}1.07 \\
(1.80)\end{array}$ & $\begin{array}{c}1.00 \\
(1.99)\end{array}$ & $\begin{array}{c}8.77 * * * \\
(1.16)\end{array}$ & $\begin{array}{c}10.17 * * * \\
(1.45)\end{array}$ & $\begin{array}{l}-1.12 \\
(0.67)\end{array}$ & $\begin{array}{l}-1.20 * \\
(0.60)\end{array}$ \\
\hline SEO for investment & $\begin{array}{c}4.11 * * * \\
(1.24)\end{array}$ & $\begin{array}{c}4.02 * * * \\
(1.26)\end{array}$ & $\begin{array}{c}4.21 * * * \\
(1.19)\end{array}$ & $\begin{array}{c}4.14 * * * \\
(1.34)\end{array}$ & $\begin{array}{c}8.65^{* * *} \\
(1.16)\end{array}$ & $\begin{array}{c}10.05^{* * *} \\
(1.45)\end{array}$ & $\begin{array}{c}2.67 * * \\
(1.26)\end{array}$ & $\begin{array}{c}2.59^{* *} \\
(1.15)\end{array}$ \\
\hline Dual-class firm SEO & $\begin{array}{c}4.68 * * * \\
(0.66)\end{array}$ & $\begin{array}{c}4.63 * * * \\
(0.65)\end{array}$ & $\begin{array}{c}4.71 * * * \\
(0.70)\end{array}$ & $\begin{array}{c}4.82 * * * \\
(0.64)\end{array}$ & $\begin{array}{c}4.01^{* * *} \\
(0.94)\end{array}$ & $\begin{array}{c}4.21^{* * *} \\
(0.95)\end{array}$ & & \\
\hline Secondary share SEO & $\begin{array}{c}5.44 * * * \\
(0.62)\end{array}$ & $\begin{array}{c}5.44 * * * \\
(0.61)\end{array}$ & $\begin{array}{c}5.43 * * * \\
(0.63)\end{array}$ & $\begin{array}{c}4.68 * * * \\
(0.47)\end{array}$ & $\begin{array}{c}6.74^{* *} \\
(3.17)\end{array}$ & $\begin{array}{l}5.59 * * \\
(2.83)\end{array}$ & & \\
\hline U.S. & $\begin{array}{c}-7.32 * * * \\
(0.94)\end{array}$ & $\begin{array}{c}-7.47 * * * \\
(1.00)\end{array}$ & $\begin{array}{c}-7.16^{* * *} \\
(1.20)\end{array}$ & $\begin{array}{c}-7.41 * * * \\
(0.88)\end{array}$ & & & & \\
\hline Network-oriented country & & $\begin{array}{l}-0.53 \\
(0.82)\end{array}$ & & & & & & \\
\hline High investor protection & & & $\begin{array}{l}-0.32 \\
(0.80)\end{array}$ & & & & & \\
\hline Top 4 journal & & & & $\begin{array}{c}2.51 * * * \\
(0.64)\end{array}$ & & $\begin{array}{c}3.15^{* *} \\
(1.23)\end{array}$ & & $\begin{array}{c}1.44 \\
(1.34)\end{array}$ \\
\hline Top 38 journal & $\begin{array}{c}0.81 \\
(1.01)\end{array}$ & $\begin{array}{c}0.77 \\
(1.00)\end{array}$ & $\begin{array}{c}0.84 \\
(1.04)\end{array}$ & $\begin{array}{l}-0.11 \\
(1.12)\end{array}$ & $\begin{array}{l}-0.50 \\
(1.06)\end{array}$ & $\begin{array}{l}-1.57 \\
(1.18)\end{array}$ & $\begin{array}{c}2.98 \\
(1.99)\end{array}$ & $\begin{array}{c}2.40 \\
(1.93)\end{array}$ \\
\hline Two-day event window & $\begin{array}{c}-0.96^{* *} \\
(0.41)\end{array}$ & $\begin{array}{c}-0.98 * * \\
(0.39)\end{array}$ & $\begin{array}{c}-0.94 * * \\
(0.43)\end{array}$ & $\begin{array}{c}-1.19 * * * \\
(0.39)\end{array}$ & $\begin{array}{l}-1.79 * \\
(1.00)\end{array}$ & $\begin{array}{l}-1.92 * \\
(0.99)\end{array}$ & $\begin{array}{l}-0.13 \\
(0.71)\end{array}$ & $\begin{array}{l}-0.30 \\
(0.77)\end{array}$ \\
\hline $\begin{array}{l}\text { Event window other than } \\
\text { 2-day or 3-day }\end{array}$ & $\begin{array}{l}2.32 * * \\
(1.02)\end{array}$ & $\begin{array}{l}2.32 * * \\
(1.01)\end{array}$ & $\begin{array}{l}2.29 * * \\
(1.04)\end{array}$ & $\begin{array}{c}2.82 * * * \\
(0.94)\end{array}$ & $\begin{array}{c}4.43 * * * \\
(1.13)\end{array}$ & $\begin{array}{c}4.62 * * * \\
(1.13)\end{array}$ & $\begin{array}{c}0.54 \\
(0.86)\end{array}$ & $\begin{array}{c}1.00 \\
(0.97)\end{array}$ \\
\hline Intercept & $\begin{array}{l}-0.14 \\
(1.19)\end{array}$ & $\begin{array}{c}0.06 \\
(1.28)\end{array}$ & $\begin{array}{l}-0.01 \\
(1.17)\end{array}$ & $\begin{array}{l}-0.20 \\
(1.27)\end{array}$ & $\begin{array}{c}-6.79 * * * \\
(0.94)\end{array}$ & $\begin{array}{c}-6.99 * * * \\
(0.95)\end{array}$ & $\begin{array}{l}-1.56 \\
(1.94)\end{array}$ & $\begin{array}{l}-1.59 \\
(2.00)\end{array}$ \\
\hline No. of observations & 448 & 448 & 448 & 448 & 253 & 253 & 195 & 195 \\
\hline R-squared & 0.30 & 0.30 & 0.30 & 0.32 & 0.25 & 0.28 & 0.24 & 0.26 \\
\hline
\end{tabular}




\section{University Library}

\section{- M M I E R R A A gateway to Melbourne's research publications}

Minerva Access is the Institutional Repository of The University of Melbourne

Author/s:

Veld, C;Verwijmeren, P;Zabolotnyuk, Y

Title:

Wealth Effects of Seasoned Equity Offerings: A Meta-Analysis

Date:

2020-03-01

Citation:

Veld, C., Verwijmeren, P. \& Zabolotnyuk, Y. (2020). Wealth Effects of Seasoned Equity Offerings: A Meta-Analysis. International Review of Finance, 20 (1), pp.77-131. https:// doi.org/10.1111/irfi.12218.

Persistent Link:

http://hdl.handle.net/11343/258574 